\title{
Benthic communities in the deep Mediterranean Sea: exploring microbial and meiofaunal patterns in slope and basin ecosystems
}

\author{
K. Sevastou ${ }^{1}$, N. Lampadariou ${ }^{1}$, P. N. Polymenakou ${ }^{2}$, and A. Tselepides ${ }^{3}$ \\ ${ }^{1}$ Hellenic Centre for Marine Research, Institute of Oceanography, P.O. Box 2214, 710 03, Heraklion, Crete, Greece \\ ${ }^{2}$ Hellenic Centre for Marine Research, Institute of Marine Biology and Genetics, P.O. Box 2214, 710 03, Heraklion, \\ Crete, Greece \\ ${ }^{3}$ University of Piraeus, Department of Maritime Studies, G. Lambraki 21 \& Distomou, 135 82, Piraeus, Greece
}

Correspondence to: K. Sevastou (sevastou@ $\mathrm{hcmr.gr)}$

Received: 16 November 2012 - Published in Biogeosciences Discuss.: 11 December 2012

Revised: 16 May 2013 - Accepted: 25 May 2013 - Published: 18 July 2013

\begin{abstract}
The long-held perception of the deep sea consisting of monotonous slopes and uniform oceanic basins has over the decades given way to the idea of a complex system with wide habitat heterogeneity. Under the prism of a highly diverse environment, a large dataset was used to describe and compare spatial patterns of the dominant smallsize components of deep-sea benthos, metazoan meiofauna and microbes, from Mediterranean basins and slopes. A grid of 73 stations sampled at five geographical areas along the central-eastern Mediterranean Basin (central Mediterranean, northern Aegean Sea, Cretan Sea, Libyan Sea, eastern Levantine) spanning over $4 \mathrm{~km}$ in depth revealed a high diversity, irrespective of the benthic group or level of taxonomic analysis. A common decreasing bathymetric trend was detected for meiobenthic abundance, major taxa diversity and nematode genera richness, but no differences were found between the two habitats (basin vs slope). In contrast, microbial richness is significantly higher at the basin ecosystem and tends to increase with depth. Multivariate analyses ( $\beta$ and $\delta$-diversity and ordination analysis) complemented these results and underlined the high within-habitat variability of benthic communities. Meiofaunal communities in particular were found to change gradually and vary more towards the abyss. On the other hand, microbial communities were highly variable, even among samples of the same area, habitat and bathymetry. A significant proportion of the variation of benthic communities and their descriptors was explained by depth and proxies of food availability (sedimentary pigments and organic content), but the combination of predictor variables and the strength of the relationship varied de-
\end{abstract}

pending on the data set used (based on type of habitat, benthic component, taxonomic level). This, along with the observed high within-habitat variability suggests that other factors, which tend to vary at local scale (hydrodynamics, substrate structure, geochemistry, food quality, etc.), may also relate to the observed benthic patterns. Overall, the results presented here suggest that differences in small-size benthos between the basin and slope habitats are neither strong nor consistent; it appears that within-habitat variability is high, differences among depth ranges are important and further investigation of possible environmental drivers of benthic patterns is needed.

\section{Introduction}

Covering more than $60 \%$ of the earth's surface and nearly $90 \%$ of the oceans, the deep sea is the largest ecosystem on earth (Ramirez-Llodra et al., 2010). Yet the deep-sea floor remains largely unexplored in spite of the enormous technological advances and the intense research efforts of the past few decades. The recent breakthroughs in deepsea research have nevertheless revealed a complex system with diverse geological, physical and biochemical characteristics that supports a wide variability of different habitats and benthic communities.

The deep sea consists of slopes and basins. The slopes are the steep part of the continental margins that connect the continental shelf with the deep-sea plains. Although of restricted size (roughly $10 \%$, Ramirez-Llodra et al., 2010), slopes are 
essential ecosystems for the functioning of the oceans and the globe, as they constitute the region where the continentto-ocean transfer of water, sediment and energy takes place. The sharp depth gradient of slopes is characterised by equally sharp environmental gradients, such as temperature and food availability. As an important component of continental margins, slopes are also characterised by high habitat heterogeneity and host diverse communities (Levin and Sibuet, 2012). In contrast, oceanic basins lack environmental gradients and are relatively uniform, appearing similar to deserts; for that reason they were long considered constant and stable environments. However, evidence now exists to support the fact that basins are dynamic environments that sustain considerable regular and episodic disturbances, such as seasonal phytodetritus deposition and benthic storms (Rex and Etter, 2010).

As most of the deep sea is heterotrophic, food supply to deep-sea benthos is derived ultimately from surface production. Primary productivity of the euphotic zone varies in space and time and so does the organic matter arriving at the deep seafloor; this may in turn lead to spatio-temporal variability in the benthos. The variability of benthic communities along the continental margins is mostly related to depth, which may, however, reflect changes in food supply, sediment characteristics or other factors. While benthic standing stocks decrease exponentially down the continental margin and reach extremely low levels in the abyssal plain (Rex et al., 2006), deep-sea biodiversity is among the highest on earth (Ramirez-Llodra et al., 2010 and references therein). A unimodal diversity-depth pattern with a mid-slope diversity maximum has been recognised for benthos, though this trend and the depth where diversity peaks are not universal and may vary among basins, regions, benthic components or taxa (Rex and Etter, 2010, Ramirez-Llodra et al., 2010, and references therein). Hence, increasing the sampling effort and extending research to include more taxa and more areas of the deep oceans will help to further elucidate bathymetric trends of benthic diversity.

In the Mediterranean, the continental shelf is very narrow and therefore the largest part of this enclosed sea is classified as deep sea. Though Mediterranean ecosystems are among the most studied areas of the world, deep-sea fauna research lags behind those of other areas (Danovaro et al., 2010). Nonetheless, considerable work carried out over the last three decades on the deep Mediterranean meiofauna has advanced our knowledge on the smallest but most abundant metazoans of the sediments (extensive bibliographic references reported in Danovaro et al. (2010) and Gambi et al. (2010)). Following major trends in ecology, recent investigations have sought for latitudinal, longitudinal and bathymetric patterns of meiofauna (Lampadariou and Tselepides, 2006; Danovaro et al., 2009a, 2010; Gambi et al., 2010), while few study differences in meiofaunal patterns among deep-sea habitats (Danovaro et al., 2009a, b; Vanreusel et al., 2010; Gambi et al., 2010). Danovaro et al. (2009a), in a study including samples from Mediterranean slopes and basins, found that meiofaunal diversity in slopes was higher than in deep-sea plains. This differs from the results reported by Vanreusel et al. (2010) that found no differences between these two habitats and partly contradicts the results of Netto et al. (2005) that found higher diversity in basins southeast of Brazil only when nematode genera diversity was considered.

Microbial benthic community studies are a recent addition to deep-sea research in the Mediterranean. A high level of bacterial richness has been recorded in the Mediterranean Sea (Luna et al., 2004; Polymenakou et al., 2005a, b, 2009), which is comparable to other deep-sea sediments (Li et al., 1999a, b; Bowman and McCuaig, 2003). Contrary to what has been found for the larger benthic components, microbial community parameters do not change with depth but remain constant (Rex et al., 2006; Danovaro et al., 2010). Recent studies dealing with bacterial diversity estimates have revealed that bacterial sequence richness found in the deep sea is similar to estimates for microorganisms living in soil or shallow water (Li et al., 1999a, b; Polymenakou et al., 2005a, 2009; Kouridaki et al., 2010; Schauer et al., 2010; Zinger et al., 2011). In addition, there is little evidence to support ubiquitous dispersal or a biogeographical pattern of sediment bacteria (Polymenakou et al., 2005b). Only recently, Zinger et al. (2011) performed an analysis of 9.6 million bacterial V6rRNA amplicons for 509 samples that span the global ocean's surface to the deep-sea floor in order to investigate global patterns of bacterial diversity. Their analysis has shown remarkable horizontal and vertical large-scale patterns in microbial communities. Overall, benthic communities appeared more diverse than pelagic communities, and a substantially higher diversity of bacterial populations was recorded in the deepsea sediments compared to open ocean surface waters, vents and anoxic ecosystems (Zinger et al., 2011).

To expand knowledge of deep-sea community spatial patterns, we examine the dominant small fractions of benthos, meiofauna and microbes. A large and detailed dataset from the central-eastern Mediterranean Basin is used for describing and comparing basin and slope ecosystems over large scale, including different geographical areas and bathymetric ranges. We pay special attention to the potential role of food availability for the observed patterns because it has been invoked as a major factor of benthic trends in the Mediterranean (Danovaro et al., 1995; Tselepides et al., 2000; Tselepides and Lampadariou, 2004; Lampadariou and Tselepides, 2006). More specifically, we aimed at investigating (1) whether meiofaunal, nematode and microbial community characteristics (abundance, diversity, composition) differ between basins and slopes; (2) whether there are bathymetric patterns for any of these community aspects comparable to worldwide patterns of deep-sea fauna; (3) whether the observed patterns are similar between the two studied habitats, within different subregions and among the different benthic components; and (4) whether the patterns resulted from the current synthesis are related to food availability. 
Table 1. Overview of projects, surveys and investigated areas involved in the present study.

\begin{tabular}{|c|c|c|c|c|c|c|}
\hline Project & Expedition & Research Vessel & Date & Area & No of Stations & Depth range $(\mathrm{m})$ \\
\hline \multirow[t]{2}{*}{ MATER } & MATER Cruise 1 & AEGAEO & Mar-97 & Northern Aegean, & 13 & $115-2273$ \\
\hline & MATER Cruise 2 & AEGAEO & Sep-97 & Cretan Sea & & \\
\hline MITTELMEER 1997/98 & METEOR 40/3 & METEOR & Dec-97 & $\begin{array}{l}\text { Northern Aegean, } \\
\text { Cretan Sea, } \\
\text { Libyan Sea }\end{array}$ & 8 & $1221-4261$ \\
\hline MATER & TransMediterranean & AEGAEO & Jun-99 & $\begin{array}{l}\text { Central Mediterranean, } \\
\text { Eastern Levantine, } \\
\text { Libyan Sea }\end{array}$ & 4 & $2950-3870$ \\
\hline ADIOS & ADIOS Cruise 2 & AEGAEO & Oct-01 & Central Mediterranean & 3 & $2786-2837$ \\
\hline BIODEEP & BIODEEP Cruise 1 & AEGAEO & Aug-01 & Central Mediterranean & 5 & $3080-3424$ \\
\hline HERMES & HERMES3 (HCMR) & AEGAEO & May-06 & $\begin{array}{l}\text { Cretan Sea, } \\
\text { Eastern Levantine, } \\
\text { Libyan Sea }\end{array}$ & 10 & $508-3603$ \\
\hline Anaximander Mountains & METEOR 71/1 & METEOR & Dec-06 & Eastern Levantine, & 1 & 1544 \\
\hline LEVAR & METEOR 71/2 & METEOR & Jan-07 & Libyan Sea & 3 & $4138-4392$ \\
\hline BIOFUN & TRANS-MED & $\begin{array}{l}\text { SARMIENTO DE } \\
\text { GAMBOA }\end{array}$ & Jun-09 & $\begin{array}{l}\text { Central Mediterranean, } \\
\text { Libyan Sea }\end{array}$ & 5 & $1204-3335$ \\
\hline ZOOTOP & MSM 14/1 & MARIA S. MERIAN & Jan-10 & Eastern Levantine, & 13 & $874-2419$ \\
\hline REDECO & REDECO Cruise 1 & AEGAEO & May-10 & Cretan Sea, & 8 & 1049-3607 \\
\hline & REDECO Cruise 2 & AEGAEO & May-11 & Libyan Sea & & \\
\hline
\end{tabular}

\section{Methods}

\subsection{Study area and sampling}

The Mediterranean Sea, an oligotrophic marine system with increased salinity, is the largest and deepest enclosed sea on earth. The Strait of Sicily divides the Mediterranean into two basins, the western and the central-eastern basins. It is characterised by many complex structural features, such as canyons, cold seeps, seamounts and mud volcanoes, and several steep environmental gradients, among which an eastward increasing salinity and temperature gradient and a southward and eastward decreasing productivity gradient. Due to the narrow continental shelf, the largest part of the Mediterranean is classified as deep sea.

In the course of 10 multidisciplinary European collaborations, benthic samples were collected during 12 oceanographic surveys at different depths in the central-eastern basin of the Mediterranean Sea (Table 1). Overall, a grid of 73 stations located at slope and basin ecosystems were sampled at 5 regions along the Mediterranean: the central Mediterranean, the northern Aegean Sea, the Cretan Sea, the Libyan Sea and the eastern Levantine (Fig. 1, Table S1). At each station, sediment samples were collected by means of multiple-core sampler, which allowed for undisturbed sediment surface sampling. All analyses were focused on the sediment surface, where the bulk of meiofauna metazoan and microfauna is gathered, i.e. $5 \mathrm{~cm}$ and $2 \mathrm{~cm}$, respectively. Meiofaunal samples were first treated with $6 \% \mathrm{MgCl}_{2}$ to relax tissues and subsequently preserved by adding $10 \%$ formalin. Sediment samples for microbial and biogeochemistry (organic carbon and chloroplastic pigment concentrations) analysis were kept frozen at $-20^{\circ} \mathrm{C}$.

\subsection{Laboratory treatment}

In the laboratory, meiofauna samples from 69 stations were sieved through 500/1000 and $30 \mu \mathrm{m}$ mesh sieves. The fauna retained on the $30 \mu \mathrm{m}$ sieve was extracted by either triplicate centrifugation or triplicate flotation, using in both cases Ludox TM colloidal silica solution of 1.18 specific gravity. After extraction, meiofauna samples were stained with Rose Bengal, counted and sorted to higher taxon level under a stereomicroscope. Nematode community analysis was based on samples from 22 out of the 69 stations. For nematode identifications, subsampling was performed so that at least 200 nematodes per sediment core were selected. After subsampling, specimens were slowly evaporated in anhydrous glycerol, evenly spread on microscope slides and identified to genus level using the pictorial keys of Platt and Warwick $(1983,1988)$, Warwick et al. (1998) as well as relevant literature dealing with new species and genera from the Mediterranean (e.g. Schuurmans Stekhoven Jr., 1950; Soetaert and Decraemer, 1989; Soetaert and Vincx, 1987).

Total microbial community DNA was extracted from approximately $1 \mathrm{~g}$ of sediment per station (UltraClean Soil kit, MoBio, Carlsbad, CA, USA) and 16S rRNA gene libraries were successfully constructed for 16 of the sampled stations (19 samples). DNA concentrations were quantified by using the NanoDrop ND-1000 UV-Vis Spectrophotometer (NanoDrop Technologies, USA). The V5-V6 region of the 16S rRNA gene was amplified by PCR. The PCR reaction mixture (final volume of $15 \mu \mathrm{L}$ ) contained $5 \mu \mathrm{L}$ of $5 \mathrm{X}$ KAPA HiFi Fidelity buffer (contains $2.0 \mathrm{mM} \mathrm{Mg}^{2+}$ at $1 \mathrm{X}$ ), $0.75 \mu \mathrm{L}$ of KAPA dNTP Mix (10 mM each dNTP), $\sim 10 \mathrm{~g}$ of template DNA and $0.50 \mu \mathrm{L}$ of KAPA HiFi HotStart DNA Polymerase $\left(1 \mathrm{U} \mu \mathrm{L}^{-1}\right)$ (KAPA Biosystems). The V5-V6 region was 


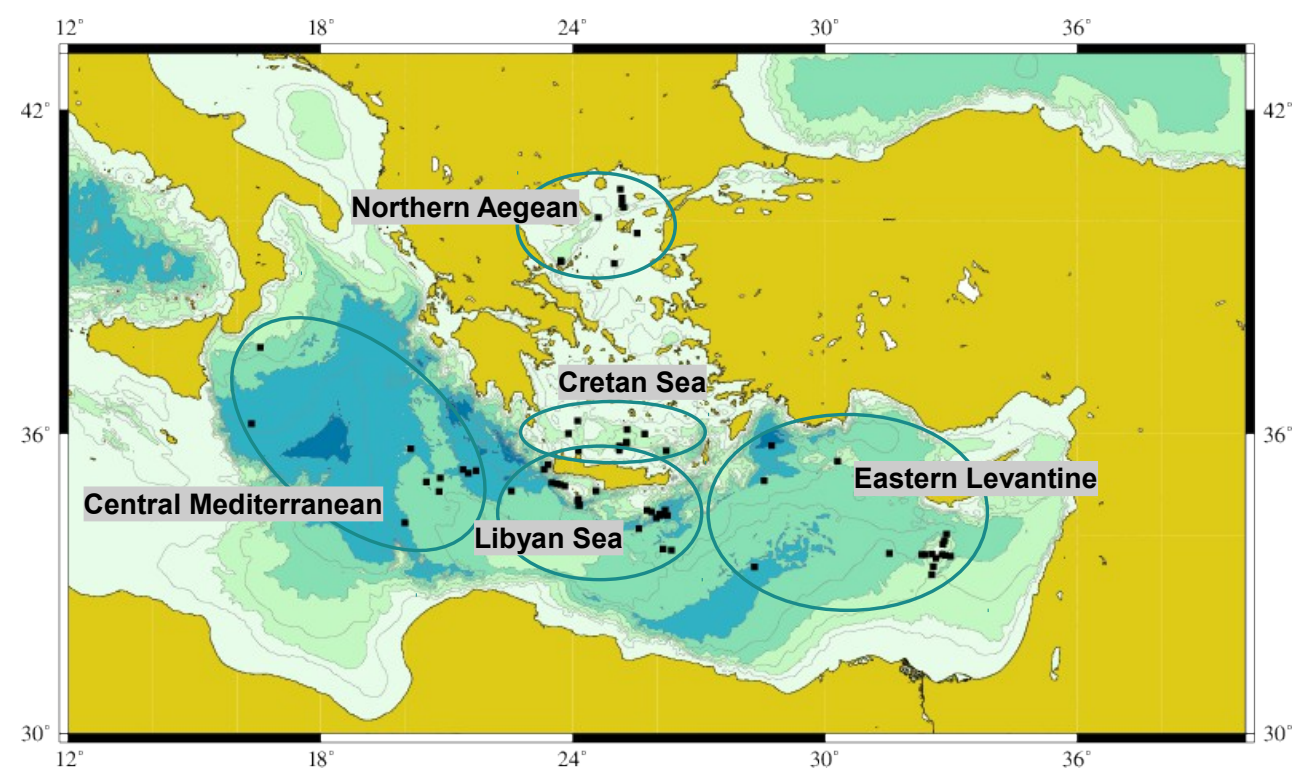

Fig. 1. Study areas and sampling stations along the Mediterranean Sea.

amplified with the following set of primers (covering bacteria and archaea): 802f (5'-GATTAGATACCCBNGTA-3') and 1027r ( $5^{\prime}$-CGACRRCCATGCANCACCT- $3^{\prime}$ ) (based on Claesson et al., 2009). The following thermal cycling program was applied: initial denaturation at $95^{\circ} \mathrm{C}$ for $5 \mathrm{~min}$, 30 cycles of denaturation at $98^{\circ} \mathrm{C}$ for $20 \mathrm{~s}$, primer annealing at $55^{\circ} \mathrm{C}$ for $15 \mathrm{~s}$, and extension at $72^{\circ} \mathrm{C}$ for $30 \mathrm{~s}$ followed by a final extension at $72^{\circ} \mathrm{C}$ for $5 \mathrm{~min}$. Quantification of the PCR products was performed using the SYBR Green stain and a QuantiFluor spectrophotometer (Promega). The sequences of the partial 16S rRNA genes were produced in the laboratories of the Institute of Marine Biology, Biotechnology and Aquaculture of the Hellenic Centre for Marine Research (Crete, Greece) by using a Roche GSFLX 454 pyrosequencer (Roche, Mannheim, Germany) following the instructions of the manufacturer for amplicon sequencing. Sequences that were shorter than $200 \mathrm{bp}$ in length were removed. Taxonomy was assigned using the Ribosomal Database Project classifier. Pyrosequencing noise was removed by using the denoiser program. Pyrosequencing data were submitted to NCBI Sequence Read Archive with the study accession number SRA054862.

Pigments (chlorophyll a (Chl $a$ ), phaeopigments (Phaeo), chlorophyll pigment equivalent (CPE)) were measured following Lorenzen and Jeffrey (1980). Total organic carbon (TOC) was measured with a Perkin Elmer CHN 2400 analyser (Hedges and Stern, 1984).

\subsection{Data analyses}

In the present study, meiofaunal and nematode diversity refer to taxon richness (TR, number of meiofaunal taxa) and genus richness (NR, number of nematode genera), respectively.
Following Whittaker's scheme (1972), we calculated TR and NR separately for three levels of inventory diversity (the diversity of a defined geographic unit): (i) for each station, identified either as basin or slope habitat, as a univariate measure of alpha diversity; (ii) for each habitat within each of the five studied areas as a univariate measure of gamma (landscape/large area) diversity; and (iii) for the whole data set that corresponds to epsilon diversity (biogeographic province diversity). The first order Jacknife estimator (Jack1) was also calculated using EstimateS v. 8.2.0 (Colwell, 2006) as an estimator of true nematode richness for the whole meiobenthic data set and for each habitat.

Differentiation diversity, i.e. the rate of change in species composition, can be measured in many different ways. Following the concept of Anderson et al. (2006), we measured beta and delta diversity using multivariate dispersion based on Jaccard dissimilarity. Beta diversity was measured (i) as the variability in taxa/genera composition among stations per habitat for each depth range/area and (ii) as the variability in taxa/genera composition among stations per depth range within each habitat. In a similar context, delta diversity was considered as the variability in taxa/genera composition among all stations for each habitat and for each depth range. Besides being flexible on the measure of dissimilarity used, the method proposed by Anderson et al. (2006) has the advantage of testing for differences in differentiation diversity through a multivariate test for homogeneity in dispersions (PERMDISP) (Anderson, 2006). Another facet of differentiation diversity, the turnover of taxa/genera between habitats and between depth ranges was also measured and for consistency was presented as Jaccard dissimilarity. 
For microbial diversity analysis, sequences were assigned to OTUs (operational taxonomic units) using the QIIME software at $3 \%$ sequence divergence (species level) according to Schloss and Handelsman (2005). Individual-based rarefaction curves at a distance level of $3 \%$ (species level) and the commonly used for microbial diversity analysis Chao1 richness estimator were calculated using the rarefaction calculator (http://www2.biology.ualberta.ca/jbrzusto/rarefact.php).

Hypothesis testing for differences in meiofauna abundance, richness (TR and NR) and meiofauna and nematode structure was done using permutational multivariate analysis of variance (PERMANOVA). Of central interest was the relationship of meiofauna descriptors with habitat type, i.e. basin and slope. Nevertheless, since it is well known that water depth affects marine sediment communities, it was necessary to consider depth range as a factor in the analysis. Thus, the overall experimental design consisted of two fixed factors: habitat, with two levels (basin, slope) and depth, with eight levels ( $<500 \mathrm{~m}, 500-1000 \mathrm{~m}, 1000-1500 \mathrm{~m}, 1500-2000 \mathrm{~m}$, 2000-2500 m, 2500-3000 m, 3000-3500 and >3500 m). $p$ values were obtained using 9999 permutations of residuals under a reduced model. DISTLM routine, a permutational regression analysis (Anderson, 2001; McArdle and Anderson, 2001; Anderson et al., 2008), was performed for exploring relationships between univariate meiofaunal and microbial variables and depth; meiofaunal, nematode and microbial community structure and depth; and univariate variables and community structure with environmental variables that possible drive benthic patterns (for simplicity, henceforth referred to as simple DISTLM, multivariate DISTLM and multiple stepwise DISTLM, respectively). These permutational analyses were based on Bray-Curtis dissimilarities of square-root transformed abundances, except from richness, for which Euclidean distances on untransformed data are considered more appropriate. To explore whether the observed bathymetric and habitat heterogeneity patterns apply to the whole Mediterranean, the permutational analyses were also applied to data sets from each area separately. PERMDISP routine was applied for measuring and exploring differences in differentiation diversity (measured as multivariate dispersion). Non-metric multi-dimensional scaling (nMDS) ordinations were used to illustrate spatial patterns of communities structure. All analyses were performed with PRIMER v6 with PERMANOVA+ add-on software (Clarke and Gorley, 2006; Anderson et al., 2008).

\section{Results}

\subsection{Meiofaunal standing stocks}

Average meiofaunal densities in the sediment surface ranged from $2 \pm 2$ ind $10 \mathrm{~cm}^{-2}$ in the deep basin of the central Mediterranean ( $2837 \mathrm{~m}$ depth) to $1249 \pm 259$ ind $10 \mathrm{~cm}^{-2}$ in the basin of the northern Aegean (1271 m depth). As ex- pected, nematodes predominated in all stations with an average percentage contribution ranging from $72 \%$ to $95 \%$ in slope stations of the Levantine and the Central Mediterranean, respectively (Fig. 2a). Other meiofauna taxa of some importance were copepods (4-16\%), polychaetes $(0.2-2 \%)$, tardigrades $(0.2-4 \%)$ and the group of soft-bodied animals (turbellarians, gnathostomulids) (0.5-4\%) (Fig. 2a).

Irrespective of the type of habitat, depth or area, meiofaunal abundance followed the pattern of nematode abundance. The lowest values were recorded at basin stations in all five areas, while the highest values were observed at slope stations only in the central Mediterranean and the Libyan Sea (Fig. 3). PERMANOVA results (Table 2) indicated differences in metazoan meiofaunal abundance between the basin and slope habitats only for two depth ranges (1000-1500 $\mathrm{m}$ and 2500-3000 m), but significant differences were detected in relation to depth and were more pronounced for the basin habitat, where meiofaunal abundance changed gradually from the shallower stations (up to $1000 \mathrm{~m}$ ) to the deeper ones $(>3000 \mathrm{~m})$. PERMANOVA analysis applied to data sets from each of the five regions separately could not distinguish meiofaunal abundances between the two habitats either (statistics not shown).

\subsection{Diversity and community structure}

\subsubsection{Meiofaunal taxa}

Overall, 27 meiofaunal taxa were encountered in all studied areas and habitats ( $\varepsilon$-diversity). Of these, only nematodes and copepods were found at all stations and samples, which along with polychaetes, tardigrades and halacaroids were found at all areas and habitats. Cnidarians were found only in slope stations, whereas aplacophorans, cumaceans, echinoderms and scaphopods were restricted to basin stations. The latter were found only at one station (northern Aegean, $1224 \mathrm{~m}$ depth).

Gamma diversity of the five studied regions (Fig. 4a) was high reaching the highest value in the Aegean Sea (24 and 23 taxa at the northern Aegean and the Cretan Sea, respectively), whereas the lowest value was found at the central Mediterranean area (13 taxa). With the exception of the eastern Levantine, the number of meiofaunal taxa was higher at the basin habitat. Nevertheless, $\alpha$-diversity range was similar between the basin and slope habitat and varied from 2 to 18 in the basins of the central Mediterranean and the northern Aegean, respectively, and from 3 to 16 at Libyan slope stations. This was supported by PERMANOVA results that showed statistically significant differences in TR among depth ranges but not between habitats (Table 2).

Delta diversity (Table 3 ) was similar at both habitats (PERMDISP $p>0.05$ ) and rather high, suggesting greater variability in meiofaunal taxa composition within $(>38 \%)$ than between habitats $(22 \%)$. At smaller scale, i.e. within each depth category, beta diversity of the two habitats (Table 4, 


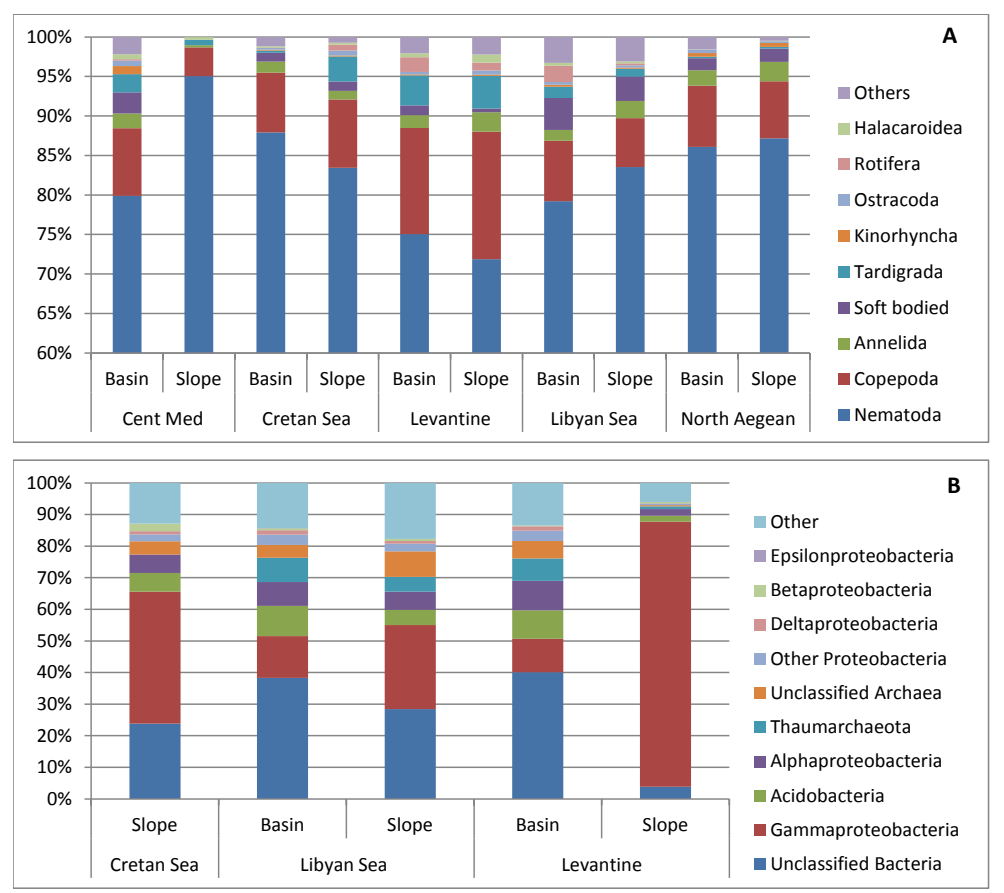

Fig. 2. Meiofauna (A) and microbial (B) composition per studied area and habitat.

within habitats) did not differ either (PERMDISP $p>0.05$ for all depth categories) but appears to increase with depth. Meiofaunal taxa turnover between basin and slope (Table 4) increases down to $1500 \mathrm{~m}$ depth, after which it appears to stabilise close to a high value $(\sim 55 \%)$.

When the different depth ranges were tested (Table 3, within depth ranges), differences in delta diversity were detected (PERMDISP $p<0.01$ ) due to the low variability in meiofauna composition among the very shallow stations $(<500 \mathrm{~m}, 13 \%)$ (PERMDISP $\mathrm{p}$ of pairwise tests $<0.05$ for all comparisons of the first depth range). Statistically significant differences were also found for beta diversity of depth ranges for the basin habitat but not for slope (Table 4, within depth ranges). Jaccard dissimilarity between depth ranges for the whole data set (Table 3) was relatively increasing for depth categories deeper than $1500 \mathrm{~m}$, indicating higher compositional differences in meiofaunal taxa towards greater depths. This pattern of bathymetric increase was stronger within the slope habitat but was not observed for basin (Table 4, between depth ranges), for which values were rather high $(89 \%$ of values $>30 \%)$ regardless of the depth category.

Community structure analysis (nMDS and PERMANOVA) confirmed the high variability in meiofauna structure within each habitat and indicated differences among depth ranges (Fig. 5a, Table 2). Meiofauna composition differed between the shallower (up to $1500 \mathrm{~m}$ depth) and the deeper stations $(>2500 \mathrm{~m}$ ), however, the difference in structure is gradual, as successive depth ranges appear similar in terms of meiofauna taxa down to $2000 \mathrm{~m}$ depth.

\subsubsection{Nematodes}

A total of 155 genera were encountered in the 22 stations where nematode community analysis was conducted. Among these, three genera were found in all stations (Acantholaimus, Halalaimus, Sphaerolaimus) and six more genera were found in all areas and habitats (Daptonema, Metasphaerolaimus, Microlaimus, Oxystomina, Pselionema, Syringolaimus). Forty-eight (48) genera were restricted to one station, of which 46 were found only in one sample.

Similar to TR, $\gamma$-diversity of nematodes peaked in the northern Aegean Sea (108 genera), but it was lowest at the most eastern part of the basin, the Levantine (22) (Fig. 4b). Alpha diversity ranged from 13 in the eastern Levantine basin habitat to 77 in the northern Aegean slope environment and, as opposed to TR, one-way PERMANOVA analysis indicated differences in the number of nematode genera between the basin and the slope habitat (Table 2). This pattern could not, however, be verified for each of the studied areas separately except from the Cretan Sea.

The number of nematode genera predicted by the species richness estimator Jack1 for the whole investigated area, the basin and the slope habitat (mean \pm SD: $160 \pm 10,128 \pm 12$ and $127 \pm 11$, respectively) is very close to the one observed in the data set $(155,123$ and 126). The estimator showed a clear sign of approaching an asymptote for the slope habitat only (Fig. 6) despite the fact that the number of samples for 
Table 2. PERMANOVA (permutational multivariate analysis of variance) results of the effects of habitat and depth for uni- and multivariate meiofaunal variables. $p$ values were obtained using 9999 permutations of residuals under a reduced model. Where statistical significant differences were indicated pairwise comparisons were done. Depth ranges with common underline are not significantly different at the $95 \%$ significance level.

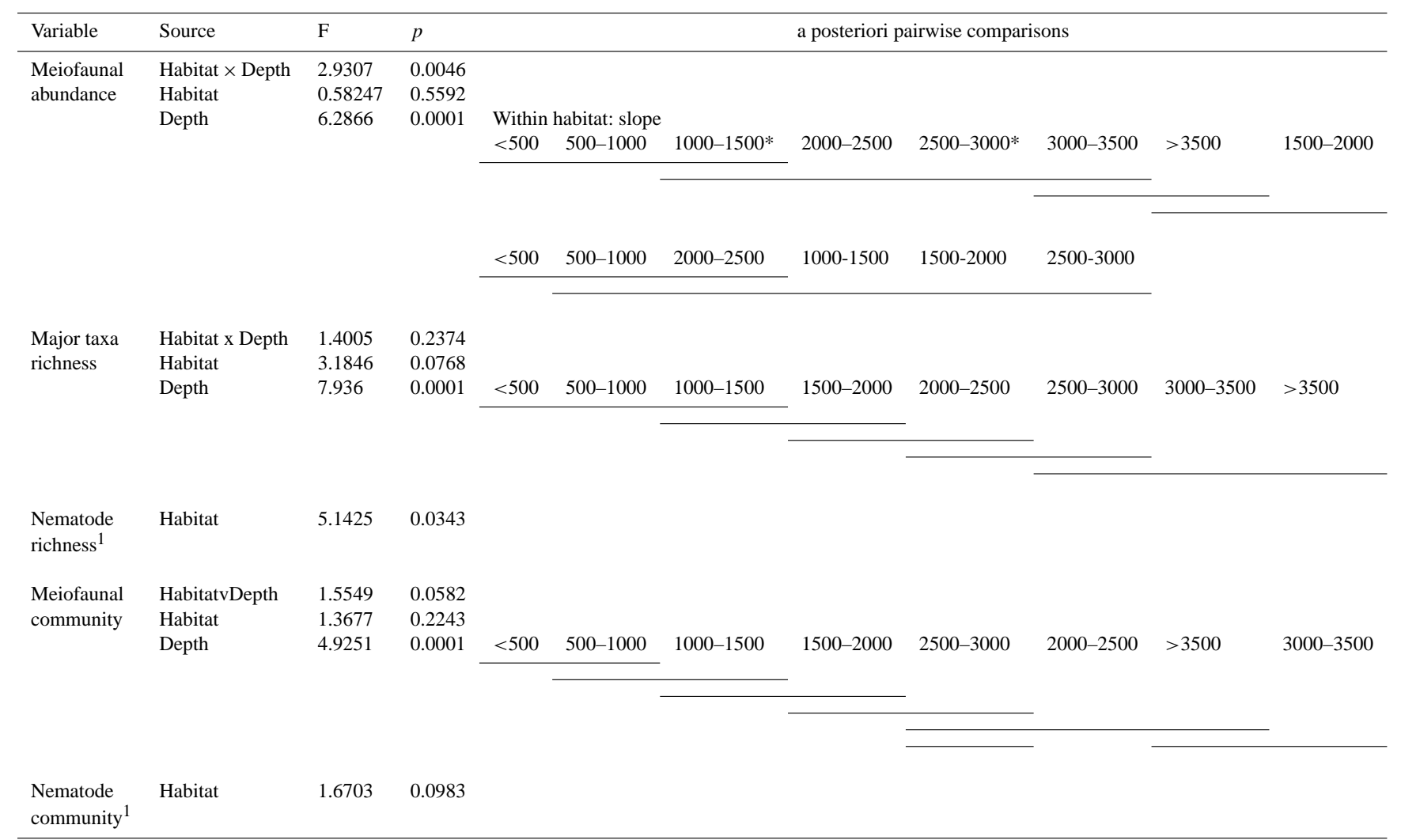

* statistically significant differences between habitats for the specific depth range at $p<0.05$.

1 One-way PERMANOVA (depth was not included in the experimental design).

this habitat is comparably low (12). As opposed to NR, Jack1 predicts no difference in nematode genera number between basin and slope, as the confidence intervals of the two curves overlap (not shown in Fig. 6).

Differentiation diversity analysis of nematode community was performed only at the level of the whole data set (delta diversity), as at smaller scales (within each habitat and within each depth range) not all levels of each factor were present. PERMDISP revealed strong differences in multivariate dispersions between the two habitats (PERMDISP $p<0.05)$ with higher delta diversity recorded at the basin habitat (Table 3, 47\%). A rather high Jaccard dissimilarity value was also recorded between the two habitats (39\%). In contrast, no differences in delta diversity were detected between the different depth ranges (PERMDISP $p>0.05$ ), which ranged from $18 \%$ at the shallowest depth range to $41 \%$ at $2500-3000 \mathrm{~m}$ depth range (Table 3). However, Jaccard dissimilarity between depth categories ranged within high values $(41-75 \%)$ suggesting high variability in nematode genera between depths.
One-way PERMANOVA analysis based on nematode community structure did not indicate differences between basin and slope (Table 2), which is also depicted in the relevant nMDS plot (Fig. 5b). However, nematode communities of most bathyal stations (down to $1000 \mathrm{~m}$ for slope and $2000 \mathrm{~m}$ for basin stations) are grouped separately from the rest, suggesting that depth has an effect on nematode community structure.

\subsubsection{Microbes}

Pyrosequencing analysis produced 55213 16S rRNA pyrotags and a total of 9587 different OTUs were finally identified from the 19 samples analysed for microbial diversity. Taxonomic analysis led to the classification of the sequences in 15 bacterial and 3 archaeal phyla and to 5 candidate divisions (Fig. 2b). Sequences were highly dominated by unidentified members of bacteria ( $34 \%$ of total sequences), while the phylum of Proteobacteria, including the five classes of Alpha-, Beta-, Gamma-, Delta- and Epsilon- proteobacteria, was the most dominant of the known bacterial groups (32\% 
Table 3. Delta diversity of major meiofaunal taxa and of nematode genera based on Jaccard dissimilarity. Values within each habitat and within each depth range were calculated using multivariate dispersion. Dissimilarity increases from 0 to 100.

\begin{tabular}{|c|c|c|c|c|c|c|c|c|}
\hline \multirow[b]{2}{*}{ Within habitats } & \multicolumn{8}{|c|}{ Major meiofaunal taxa } \\
\hline & $\begin{array}{r}\text { Basin } \\
42\end{array}$ & $\begin{array}{r}\text { Slope } \\
38\end{array}$ & & & & & & \\
\hline Between habitats & 22 & & & & & & & \\
\hline Within depth ranges** & $\begin{array}{r}<500 \\
13\end{array}$ & $\begin{array}{r}500-1000 \\
33\end{array}$ & $\begin{array}{r}1000-1500 \\
39\end{array}$ & $\begin{array}{r}1500-2000 \\
39\end{array}$ & $\begin{array}{r}2000-2500 \\
30\end{array}$ & $\begin{array}{r}2500-3000 \\
39\end{array}$ & $\begin{array}{r}3000-3500 \\
36\end{array}$ & $\begin{array}{r}>3500 \\
41\end{array}$ \\
\hline Between depth ranges & $<500$ & $500-1000$ & $1000-1500$ & $1500-2000$ & $2000-2500$ & $2500-3000$ & $3000-3500$ & \\
\hline $500-1000$ & 26 & & & & & & & \\
\hline $1000-1500$ & 31 & 22 & & & & & & \\
\hline $1500-2000$ & 33 & 17 & 22 & & & & & \\
\hline $2000-2500$ & 48 & 36 & 46 & 43 & & & & \\
\hline $2500-3000$ & 29 & 18 & 31 & 18 & 32 & & & \\
\hline $3000-3500$ & 35 & 39 & 42 & 32 & 39 & 26 & & \\
\hline \multirow[t]{2}{*}{$>3500$} & 45 & 42 & 38 & 35 & 42 & 38 & 37 & \\
\hline & \multicolumn{8}{|c|}{ Nematode genera } \\
\hline Within habitats* & $\begin{array}{r}\text { Basin } \\
47\end{array}$ & $\begin{array}{r}\text { Slope } \\
41\end{array}$ & & & & & & \\
\hline Between habitats & 39 & & & & & & & \\
\hline Within depth ranges & $\begin{array}{r}<500 \\
18\end{array}$ & $\begin{array}{r}500-1000 \\
\mathrm{n} / \mathrm{a}\end{array}$ & $\begin{array}{r}1000-1500 \\
38\end{array}$ & $\begin{array}{r}1500-2000 \\
36\end{array}$ & $\begin{array}{r}2000-2500 \\
28\end{array}$ & $\begin{array}{r}2500-3000 \\
41\end{array}$ & $\begin{array}{r}3000-3500 \\
39\end{array}$ & $\begin{array}{r}>3500 \\
30\end{array}$ \\
\hline Between depth ranges & $<500$ & $500-1000$ & $1000-1500$ & $1500-2000$ & $2000-2500$ & $2500-3000$ & $3000-3500$ & \\
\hline $500-1000$ & 44 & & & & & & & \\
\hline $1000-1500$ & 47 & 47 & & & & & & \\
\hline $1500-2000$ & 47 & 50 & 48 & & & & & \\
\hline $2000-2500$ & 57 & 63 & 56 & 60 & & & & \\
\hline $2500-3000$ & 65 & 66 & 61 & 57 & 53 & & & \\
\hline $3000-3500$ & 59 & 60 & 56 & 60 & 41 & 51 & & \\
\hline$>3500$ & 75 & 75 & 75 & 72 & 67 & 62 & 61 & \\
\hline
\end{tabular}

of total sequences). The next most dominant phylum was the Acidobacteria ( $7 \%$ of total sequences) followed by the archaeal phylum of Thaumarchaeota (6\% of total sequences). Microbial community composition appeared to be similar between slope and basin stations at the level of large taxonomic groups, except from the slope station in Levantine, where the class of Gammaproteobacteria was highly dominant (Fig. 2b). However, this could be a random effect, as microbial community composition in slopes of the Levantine is based on the analysis of a single station.

Richness was much higher at the basin compared to the slope habitat, accounting for 7969 and 3329 different OTUs, respectively, while the Chao1 richness estimator, based on the whole data set, predicted 19489 different OTUs (Fig. 6). A small proportion of OTUs ranging from 2 to $28 \%$ were singletons (i.e. occurred only once in the full dataset) and they accounted for approximately $10 \%$ of all sequences. Jaccard dissimilarity between the two habitats ( $82 \%)$, among depth ranges ( $>77 \%)$ and samples ( $>78 \%$ ) was very high, clearly indicating high variability of microbial communities at all spatial scales. This was further supported by nMDS analysis as the lack of apparent grouping could not reveal any spatial pattern or gradient (Fig. 5c).

\subsection{Benthos and environmental variables: bathymetric trends and food availability}

Simple DISTLM analysis complemented PERMANOVA results, indicating that depth explains a significant amount of the variation in meiofaunal abundance and richness (Table 5), which decrease with increasing water depth (Fig. 7). The variation explained was higher for basin as compared to slope habitat for abundance and TR, but it was not statistically significant for NR when slope stations were only considered (Table 5). Microbial diversity, on the other hand, was found to be only marginally significantly dependent on depth when the whole microbial data set was investigated (Table 5), 
Table 4. Beta diversity based on major meiofaunal taxa Jaccard dissimilarity. Values within each habitat and within each depth range were calculated using multivariate dispersion. Dissimilarity increases from 0 to 100.

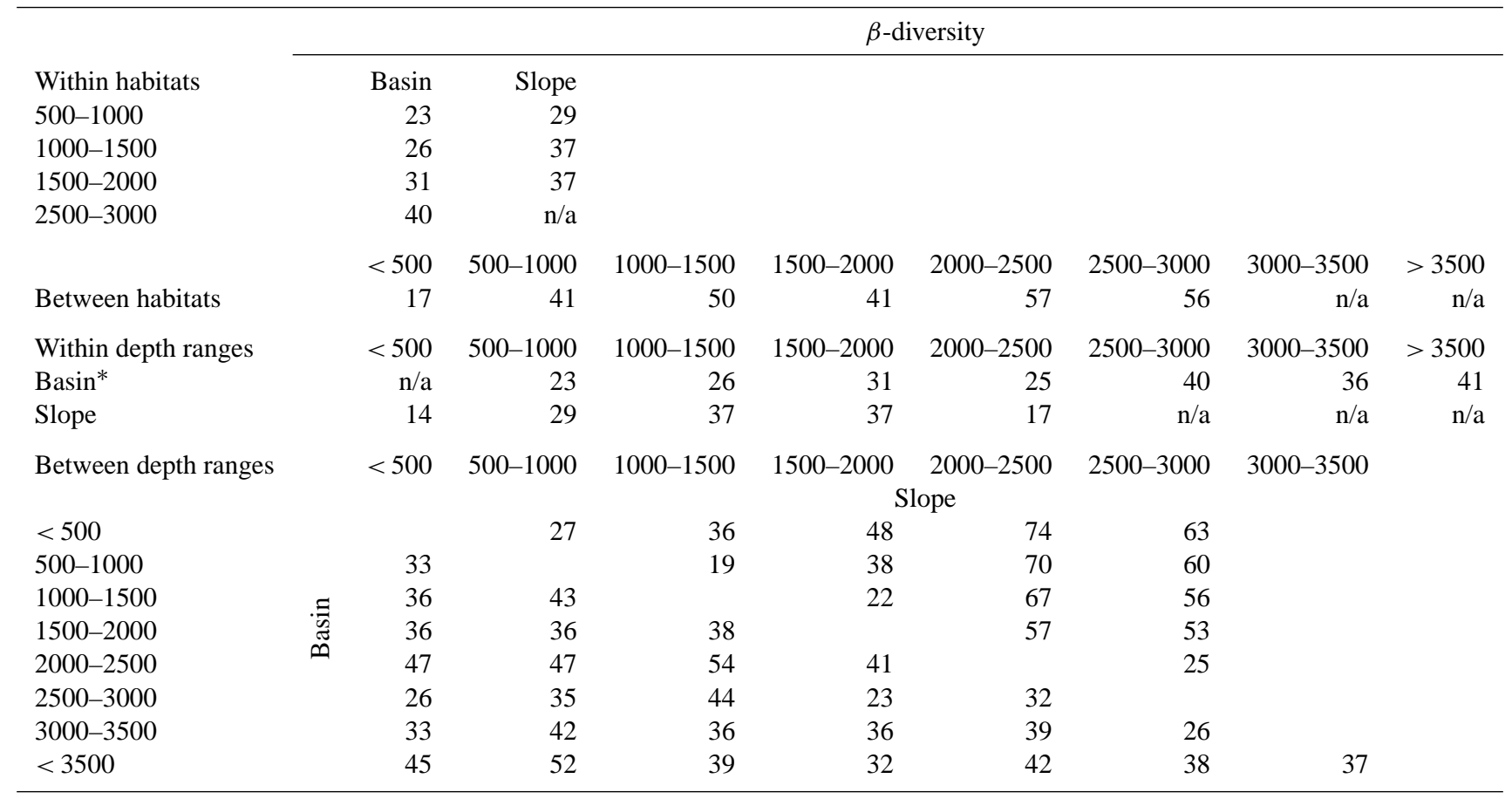

* Statistically significant differences among levels of the factor "depth range" for the basin habitat at $p<0.05$; n/a: Few samples for running PERMDISP.

suggesting that microbial richness, opposite to the meiofaunal variables, tends to increase with depth (Fig. 7). However, this trend could not be verified for each of the two habitats. Similar to simple DISTLM, multivariate DISTLM analysis used to investigate the bathymetric patterns of benthic communities indicated that depth explains a significant variation of the structure of both meiofaunal and nematode community but not of microbial, although it suggests $(p=0.045)$ correlation of microbes with depth when the slope stations are only investigated (Table 5).

When food availability is also considered, multiple stepwise DISTLM (Table 6) reveals that depth remains the most important factor in explaining meiofaunal variability, along with one of the proxies of food availability for all cases except from nematode richness, for which depth alone explains $73 \%$ of its variance. Similar results are provided when the basin habitat is only investigated, but at the slope habitat the importance of food availability is increasing and becomes the sole factor, explaining more than $60 \%$ of the variance in meiofaunal and nematode richness and nematode community. On a similar note, depth is also the only factor explaining at a high rate $(>60 \%)$ the variance of microbial richness; yet, this is not verified for the slope habitat, whereas sedimentary organic carbon is the sole variable suggested for explaining microbial richness variability in the basin habitat. In contrast, neither depth nor any of the proxies of food availability used in this study could explain the variability of Mediterranean microbial community.

\section{Discussion}

\subsection{Standing stocks in the deep sea}

In the energy-poor environment of the deep sea, many community parameters seem linked to food supply. The Mediterranean Sea has low levels of productivity, particularly the Eastern Basin (Psarra et al., 2000), which results in extremely low organic content in deep sediments (Danovaro et al., 1999). Therefore, benthic standing stocks in the Mediterranean are expected to be depressed. Nevertheless, there are areas in the Mediterranean Sea which are more productive. Such an area is the northern Aegean Sea, which is enriched by riverine outflows and the influx of nutrient-rich Black Sea waters (Poulos et al., 1997; Lykousis et al., 2002). As a consequence, higher faunal densities are anticipated for this area. The meiofaunal abundances reported in the present synthesis are indeed lower from those of similar depths in other oceans (for an extensive reference report see Gambi et al., 2010) but comparable to those recorded from similar Mediterranean deep-sea sediments (Tselepides and Lampadariou, 2004; Lampadariou and Tselepides, 2006; Lampadariou et al., 2009; Gambi et al., 2010), yet they fall within a wider range of values. Our data also confirms the prediction 

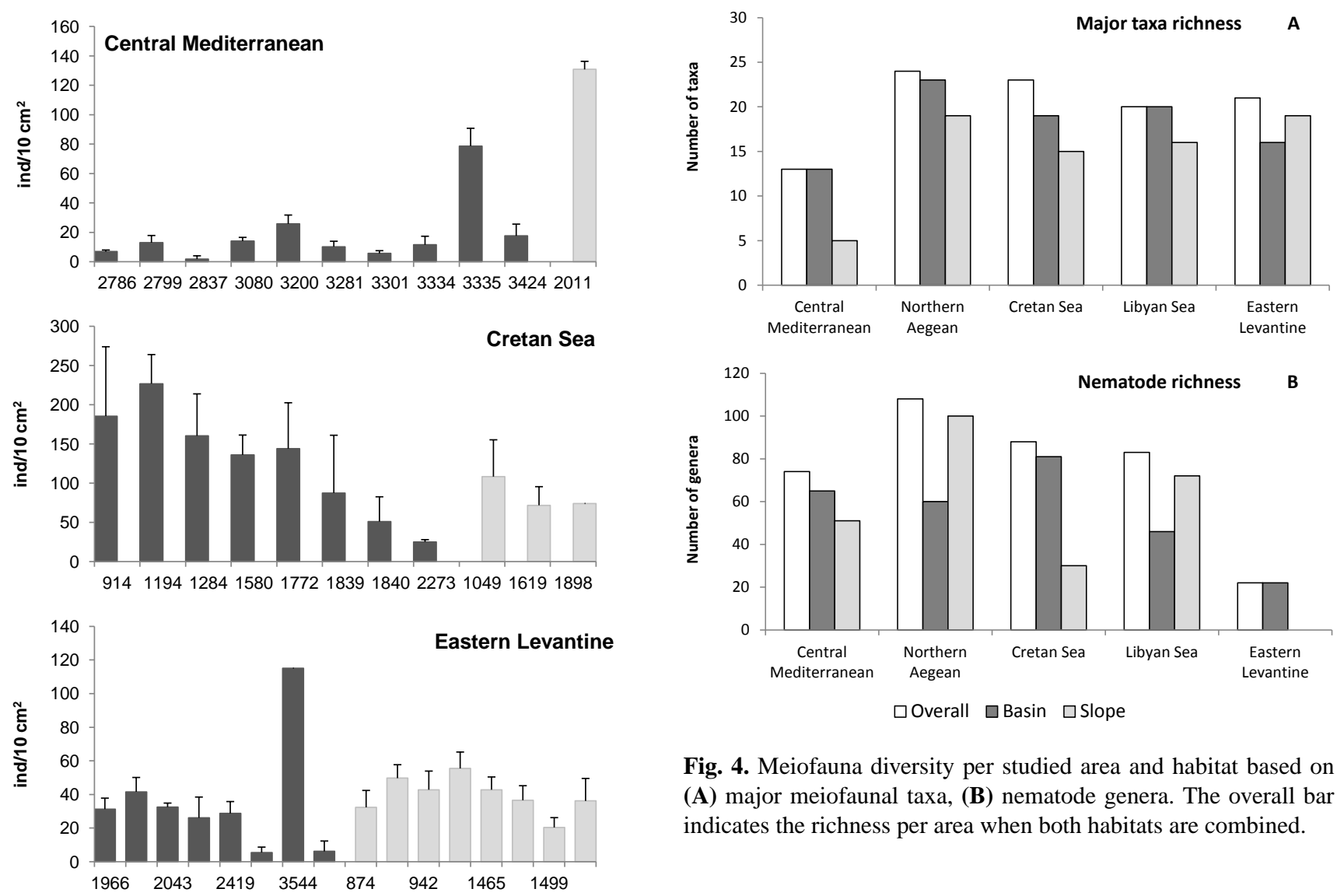

Fig. 4. Meiofauna diversity per studied area and habitat based on (A) major meiofaunal taxa, (B) nematode genera. The overall bar indicates the richness per area when both habitats are combined.
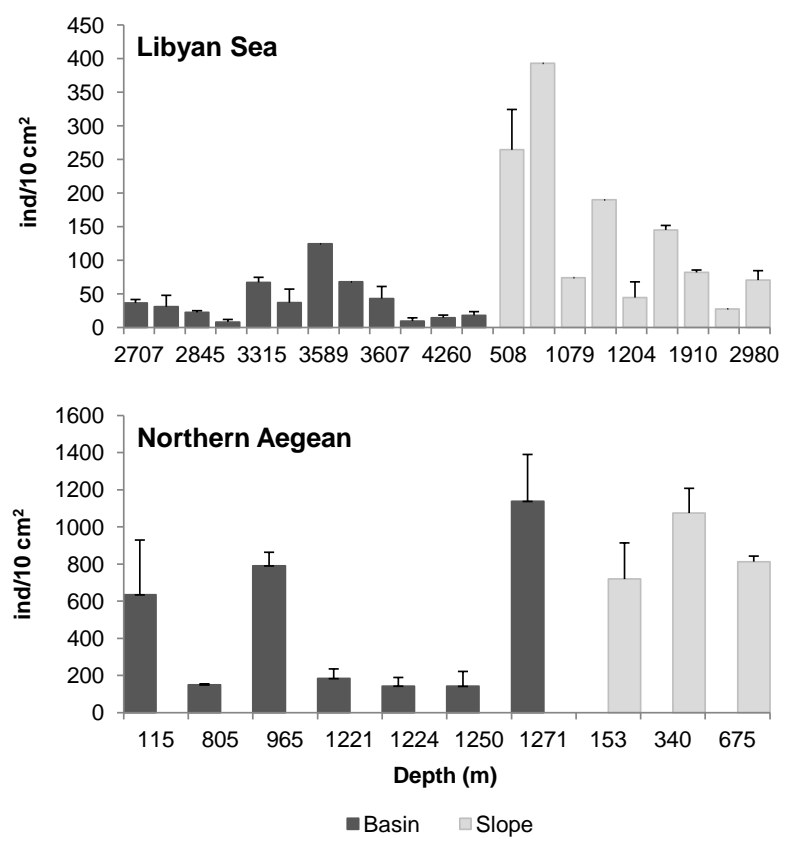

Fig. 3. Nematode abundance per studied area and habitat in relation to depth. Note in $\mathrm{x}$-axis the arrangement of depth in increasing order for each habitat.

of higher faunal densities in the northern Aegean Sea, as the higher meiofaunal density was measured in this area.

One of the best known gradients in marine sediments is that of abundance with water depth. Similar to all benthic groups, the relationship of meiofaunal density and depth has been found to be significant and negative (Rex et al., 2006). This general pattern has been mainly related to organic matter input, food limitation and food quality (Rex et al., 2006; Soltwedel, 2000), although it is also suggested to be locally influenced by a number of factors such as the hydrography of the area and the sediment type (Gambi et al., 2010; Rex and Etter, 2010). Our results are in agreement with this general bathymetric trend of abundance and indicate the existence of this pattern for meiofauna in all the eastern Mediterranean basins irrespective of the type of habitat. Nevertheless, it was only in the slope habitat that a strong relation with food availability was indicated, suggesting that despite both habitats sharing the same bathymetric pattern, the underlying mechanisms differ. It appears that the response of meiofauna to the organic matter content in basins is affected by other possible drivers of meiobenthic patterns, such as food quality, local hydrodynamics, sediment texture, or even inherent population characteristics (life cycle, metabolic activity, etc.).

In a pan-Mediterranean deep-sea meiofauna review study based on primarily literature data from 195 sites, Gambi et al. (2010) reported that meiobenthic abundances at slopes were higher than other investigated types of habitats, 

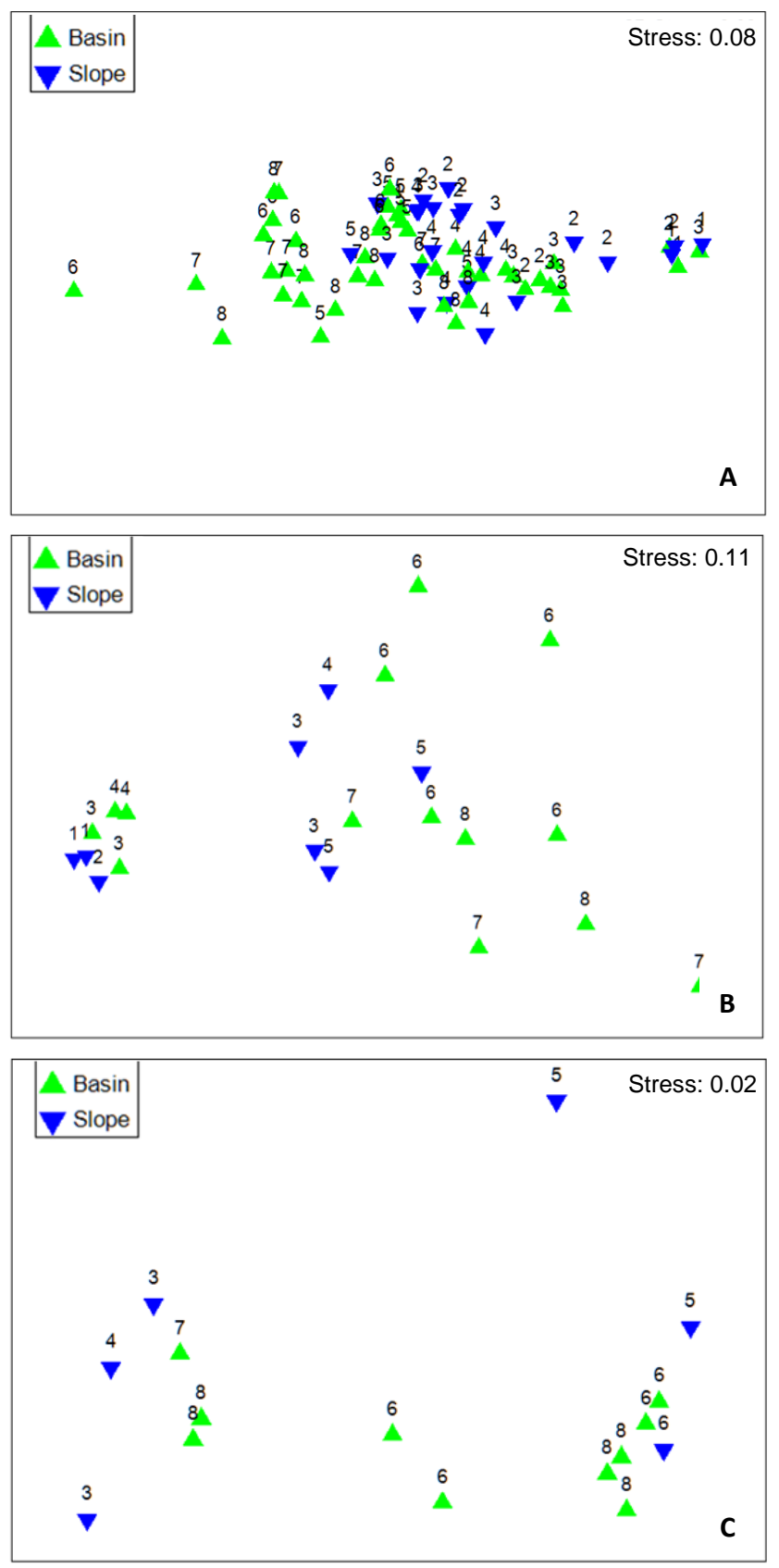

Fig. 5. nMDS ordination based on (A) major meiofaunal taxa, (B) nematode genera composition and (C) microbial OTUs. Numbers indicate the different depth ranges. $1:<500 \mathrm{~m} ; 2: 500-1000 \mathrm{~m} ; 3$ : 1000-1500 m; 4: 1500-2000 m; 5: 2000-2500 m; 6: 2500-3000 m; 7: 3000-3500 m; 8: > $3500 \mathrm{~m}$.

including basins. Our findings contradict these results, but are in agreement with Netto et al. (2005) who found no differences between the two habitats when studying a slope and a basin site of 215 and $890 \mathrm{~m}$ depth, respectively, in an oligotrophic deep-sea site off SE Brazil. Because slope stations are usually found in shallower areas, higher meiofaunal
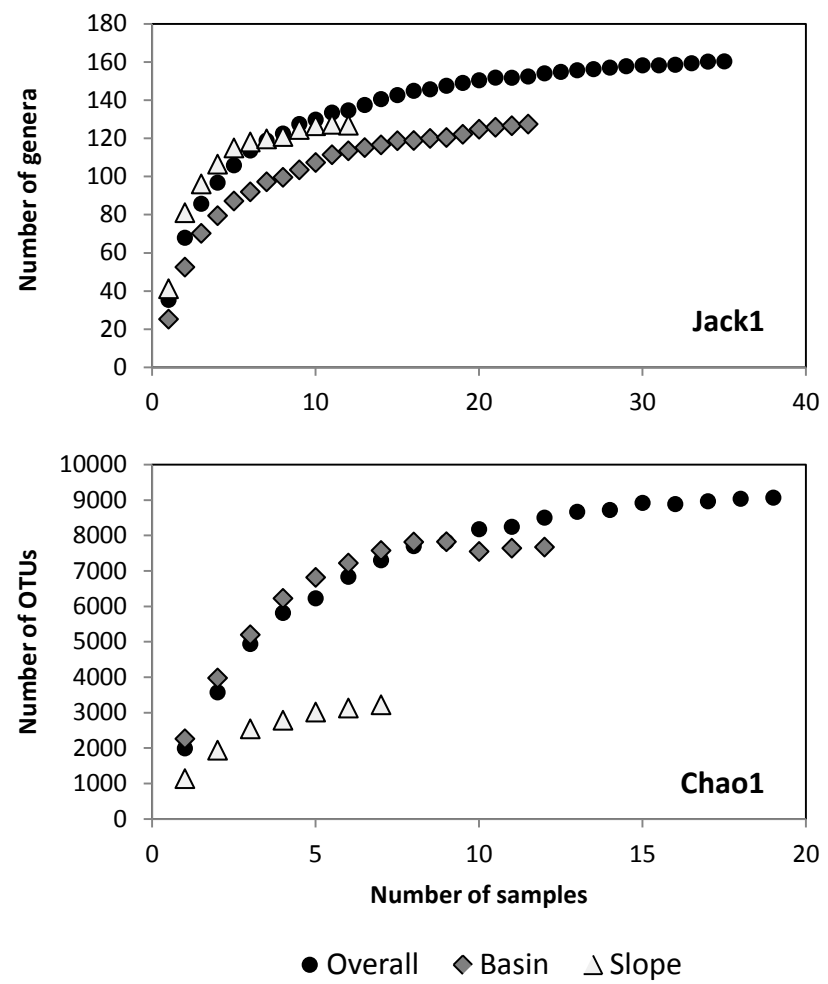

Fig. 6. Richness estimators Jack1 and Chao1 for nematode genera and microbial OTUs, respectively. The overall line indicates estimates for the whole data set.

abundances would be expected at this habitat. However, the wide range of meiofaunal abundance observed within each of these two habitats in both our study and that of Netto et al. (2005) could not allow for statistical significant differences to be detected, suggesting the existence of high environmental variability at small (Netto et al., 2005) or large (present study) scale within both basin and slope environments. This spatial heterogeneity may also be related to the aforementioned factors that are known to be important in shaping meiobenthic patterns and may vary at local scale (sediment type, food, hydrodynamics).

\subsection{Small-size benthos diversity in the Mediterranean}

Our study demonstrates that the diversity of the small-size benthos in the Mediterranean deep sea is high, irrespective of the taxonomic group or level of taxonomic analysis. The number of meiobenthic metazoan taxa encountered in our study is higher than any other reported not only in the Mediterranean Sea but worldwide (Gambi et al., 2010 and references therein). This finding could be an artefact of the treatment of the data sets; in most review or synthesis papers, ambiguous taxa are usually grouped together (e.g. different classes of Mollusca), while in the present synthesis, meiofauna classification was retained down to the lowest possible level because all samples were treated by the same 

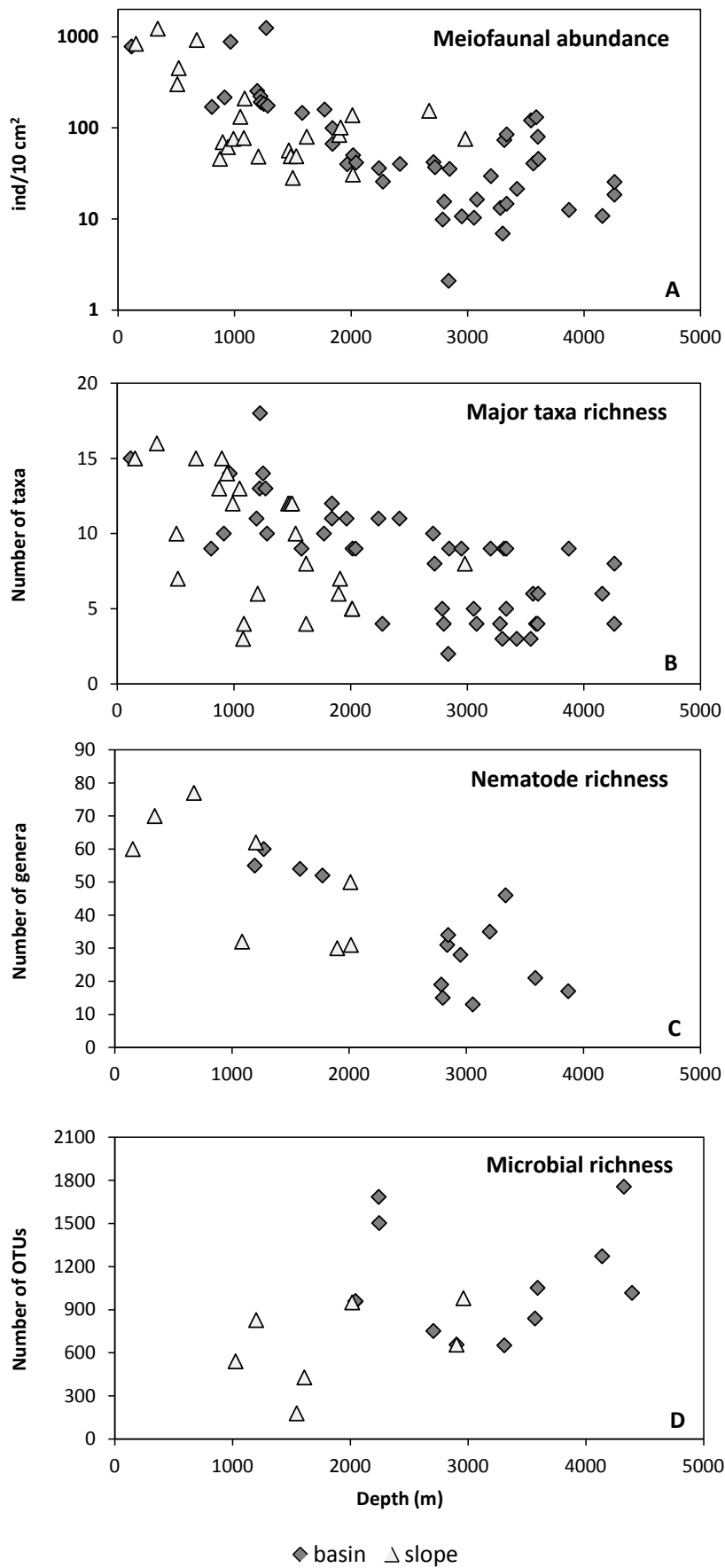

Fig. 7. Bathymetric gradient of (A) meiofaunal abundance $(n=69)$, (B) major taxa richness $(n=69)$, (C) nematode genus richness $(n=$ $22)$ and $(\mathbf{D})$ microbial richness $(n=19)$. Note the logarithmic scale for meiofaunal abundance.

research group. The number of nematode genera identified in the present study (155) is most probably the highest reported until now from the Mediterranean deep sea (extensive bibliographic report in Miljutin et al., 2010), as only Soetaert and Heip (1995) found a higher number of genera (163), but based on deep-sea and shelf-break sites from the Mediter-
Table 5. Results of DISTLM analysis, a permutational regression routine, for exploring relationships of meiofauna and microbes with depth. $p$ values were obtained using 9999 permutations of residuals.

\begin{tabular}{|c|c|c|c|}
\hline Variable & $F$ & $p$ & Variability \\
\hline \multicolumn{4}{|l|}{ Overall } \\
\hline Meiofauna abundance & 43.261 & $* *$ & 0.392 \\
\hline Major taxa richness & 44.478 & $* *$ & 0.399 \\
\hline Nematode richness & 35.299 & $* *$ & 0.638 \\
\hline Microbial richness & 4.851 & $*$ & 0.222 \\
\hline Meiofaunal community & 30.290 & $* *$ & 0.311 \\
\hline Nematode community & 7.508 & $* *$ & 0.273 \\
\hline Microbial community & 1.278 & $\mathrm{n} / \mathrm{s}$ & 0.070 \\
\hline \multicolumn{4}{|l|}{ Basin } \\
\hline Meiofauna abundance & 31.111 & $* *$ & 0.420 \\
\hline Major taxa richness & 48.147 & $* *$ & 0.528 \\
\hline Nematode richness & 19.624 & $*$ & 0.621 \\
\hline Microbial richness & 0.072 & $\mathrm{n} / \mathrm{s}$ & 0.007 \\
\hline Meiofaunal community & 21.238 & $* *$ & 0.331 \\
\hline Nematode community & 5.914 & $* *$ & 0.330 \\
\hline Microbial community & 0.698 & $\mathrm{n} / \mathrm{s}$ & 0.065 \\
\hline \multicolumn{4}{|l|}{ Slope } \\
\hline Meiofauna abundance & 10.727 & * & 0.328 \\
\hline Major taxa richness & 8.217 & $*$ & 0.272 \\
\hline Nematode richness & 5.612 & $\mathrm{n} / \mathrm{s}$ & 0.483 \\
\hline Microbial richness & 0.722 & $\mathrm{n} / \mathrm{s}$ & 0.126 \\
\hline Meiofaunal community & 9.757 & $* *$ & 0.307 \\
\hline Nematode community & 4.378 & $*$ & 0.422 \\
\hline Microbial community & 1.788 & $*$ & 0.263 \\
\hline
\end{tabular}

ranean and the North Atlantic. The number of uniques found in our study ( $30 \%$ of nematode genera restricted to one station) is typical for marine soft sediments, which are dominated by rare species at all scales (Gray et al, 2005).

Meiobenthic $\gamma$-diversity of the five studied areas was also high, regardless of the taxonomic level of the analysis, and peaked in the Aegean Sea. The lowest number of major meiofaunal taxa found at the central Mediterranean area is consistent with previous bibliographic reports (Gambi et al., 2010 and references therein), however it may be related to the lowest sampling effort from this region. On the other hand, the lower nematode genus richness in the most eastern part of the basin, the Levantine, may well depict the well-known west-eastward decrease of productivity and may also be an indication for a link between surface productivity and deepsea nematode diversity (Lampadariou and Tselepides, 2006; Lambshead et al., 2000, 2002).

Microbial diversity at the phylum level was also high. The dominance of Proteobacteria in all stations demonstrated the cosmopolitan character of this group of microorganisms, while the strong presence of Acidobacteria is consistent with previous investigations in the eastern Mediterranean 
Table 6. Results of multiple stepwise DISTLM analysis, a permutational regression routine, for exploring relationships of meiofauna and microbes with environmental (predictor) variables. $p$ values were obtained using 9999 permutations of residuals under a reduced model. For each response variable only the best model (based on Adjusted $R^{2}$ ) with the variables that significantly contribute to explain the variance are provided. TOC: total organic carbon; CPE: chlorophyll pigment equivalent; ns: statistically not significant $(p>0.05)$.

\begin{tabular}{|c|c|c|c|c|c|}
\hline Response variable & Predictor variable & $F$ & $p$ & Variability & Cummulative variability \\
\hline \multicolumn{6}{|l|}{ Overall } \\
\hline \multirow[t]{2}{*}{ Meiofauna abundance } & Depth & 55.450 & 0.0001 & 0.531 & 0.531 \\
\hline & $\%$ TOC & 4.170 & 0.0159 & 0.037 & 0.568 \\
\hline \multirow[t]{2}{*}{ Major taxa richness } & Depth & 33.694 & 0.0001 & 0.407 & 0.407 \\
\hline & CPE & 32.544 & 0.0001 & 0.239 & 0.647 \\
\hline Nematode richness & Depth & 40.446 & 0.0001 & 0.729 & 0.729 \\
\hline Microbial richness & Depth & 17.817 & 0.0013 & 0.664 & 0.664 \\
\hline \multirow[t]{2}{*}{ Meiofaunal community } & Depth & 35.427 & 0.0001 & 0.420 & 0.420 \\
\hline & Phaeo & 5.452 & 0.0005 & 0.059 & 0.479 \\
\hline \multirow[t]{2}{*}{ Nematode community } & Depth & 7.988 & 0.0001 & 0.347 & 0.347 \\
\hline & CPE & 2.207 & 0.0136 & 0.089 & 0.436 \\
\hline Microbial community & \multicolumn{5}{|c|}{$\mathrm{n} / \mathrm{s}$} \\
\hline \multicolumn{6}{|l|}{ Basin } \\
\hline Meiofauna abundance & Depth & 31.970 & 0.0001 & 0.470 & 0.470 \\
\hline \multirow[t]{2}{*}{ Major taxa richness } & Depth & 43.679 & 0.0001 & 0.548 & 0.548 \\
\hline & CPE & 20.360 & 0.0001 & 0.166 & 0.714 \\
\hline Nematode richness & Depth & 34.880 & 0.0010 & 0.777 & 0.777 \\
\hline Microbial richness & $\% \mathrm{TOC}$ & 7.897 & 0.0278 & 0.612 & 0.612 \\
\hline \multirow{2}{*}{ Meiofaunal community } & Depth & 22.475 & 0.0001 & 0.384 & 0.384 \\
\hline & CPE & 3.287 & 0.0123 & 0.053 & 0.437 \\
\hline Nematode community & Depth & 6.083 & 0.0003 & 0.378 & 0.378 \\
\hline Microbial community & \multicolumn{5}{|c|}{$\mathrm{n} / \mathrm{s}$} \\
\hline \multicolumn{6}{|l|}{ Slope } \\
\hline \multirow[t]{3}{*}{ Meiofauna abundance } & $\%$ TOC & 17.622 & 0.0019 & 0.616 & 0.616 \\
\hline & $\mathrm{Phaeo}^{1}$ & 8.275 & 0.0044 & 0.174 & 0.790 \\
\hline & Depth & 6.147 & 0.0303 & 0.085 & 0.875 \\
\hline Major taxa richness & Phaeo $^{1}$ & 18.725 & 0.0029 & 0.630 & 0.630 \\
\hline Nematode richness & $\%$ TOC & 96.665 & 0.0156 & 0.970 & 0.970 \\
\hline Microbial richness & \multicolumn{5}{|c|}{$\mathrm{ns}$} \\
\hline \multirow[t]{3}{*}{ Meiofaunal community } & Depth & 10.051 & 0.0007 & 0.477 & 0.477 \\
\hline & Phaeo $^{1}$ & 5.257 & 0.0039 & 0.180 & 0.658 \\
\hline & $\mathrm{CPE}^{1}$ & 2.469 & 0.0463 & 0.074 & 0.731 \\
\hline Nematode community & $\% \mathrm{TOC}$ & 6.030 & 0.0248 & 0.668 & 0.668 \\
\hline Microbial community & \multicolumn{5}{|c|}{ ns } \\
\hline
\end{tabular}

${ }^{1}$ Because of skewness of raw data, $\log (x+1)$ transformation was applied.

Sea and the deep South Atlantic (Kouridaki et al., 2010; Polymenakou et al., 2005a, 2009; Quaiser et al., 2008). Although Acidobacteria are ubiquitous members of soil bacterial communities (Jones et al., 2009) our study supports previous observations, which suggest the wide distribution of this microbial group in the Mediterranean deep sea.

In a recent study on global patterns of marine microbial communities Zinger et al. (2011) obtained more than 120000 OTUs, of which almost 41000 were reported in the deep sea. In the Mediterranean deep-sea sediments, bacterial richness has been found to range from 13 to 1306 OTUs per gram of surface sediment (Luna et al., 2004; Polymenakou et al., 2005b, 2009), but estimations exceed 4000 species
(Danovaro et al., 2010). In our study, microbial communities of the deep Mediterranean Sea were analysed by applying 454 pyrosequencing, which is expected to increase significantly the estimates of microbial species richness (Danovaro et al., 2010). Indeed, a much higher number of microbial OTUs (9587) than any previously reported from the Mediterranean deep-sea was detected in the present study, while Chaol richness estimator predicted a number which is at least one order of magnitude higher than any previous estimates from the Mediterranean sediments ( $\sim 1306$ OTUs in Polymenakou et al., 2005b). The number of singletons, on the other hand, was relatively low (10\% of all sequences) compared to those typically found in marine ecosystems 
( $\sim 50 \%$ of sequences; Zinger et al., 2011). From these results it appears that the deep Mediterranean sediments harbour an incredibly high microbial diversity comparable to values found in the highly diverse soil environments (e.g. $\sim 3200$ OTUs in forest soils as reported by Nacke et al., 2011). However, it has to be noted that direct comparisons to previous studies is difficult, as the number of analysed sequences per sample in pyrosequencing has an effect on the predicted number of OTUs (Nacke et al., 2011).

\subsubsection{Bathymetric patterns of alpha diversity}

Biodiversity research in the deep sea has largely concentrated on revealing bathymetric patterns of benthic communities. For many taxa, mainly macrobenthic, a parabolic pattern has been described (reviewed in Rex and Etter, 2010) with a maximum at intermediate depths, i.e. between 1500 and $2500 \mathrm{~m}$, while several factors, such as surface productivity, geology, hydrology and evolutionary history of the area, are hypothesised for the explanation of the observed trends. On the other hand, bathymetric patterns of meiofaunal diversity have been generally found to be similar to that of abundance, with a decrease in richness with increasing depth for major taxa (Danovaro et al., 2008, 2009b; Gambi et al., 2010) and copepod species (Baguley et al., 2006), whereas nematode richness patterns are either absent or not consistent among different areas or habitat types (Lampadariou and Tselepides, 2000; Danovaro et al., 2009a, b, 2010). Our results are in agreement with the general trend of meiobenthic diversity, as non-parametric regression analysis revealed a highly significant negative correlation of TR and NR with depth within the whole investigated area and within each type of habitat. Moreover, the high variability explained by depth for the basin ecosystem suggests that the decrease in diversity with depth in this habitat is sharper. The observed bathymetric pattern was not, however, discernible within each of the investigated areas. This, along with the finding that different food proxies (CPE, Phaeo, TOC) relate at different levels with meiofaunal richness depending on habitat type and taxon, provide strong support for the suggestion of Danovaro et al. (2009a) that meiobenthic diversity patterns depend also on topographic and ecological features.

Although there is a considerable gap in the study of spatial microbenthic patterns, it has been found that microbial diversity is similar among sediments of variable bathymetry and thus it is not affected by depth (Li et al, 1999a; Danovaro et al., 2010; Polymenakou personal observation). Similar results were reported by Bienhold et al. (2012) that studied microbial communities at depth transects across the Arctic continental margin, as richness was found to correlate with sedimentary pigment concentrations but not water depth. Contrary to those previous observations and opposite to the metazoan patterns, our results suggest an increase of microbial richness with depth, which could not, however, be verified independently within each of the two studied habitats. In
Tselepides et al. (2007), the authors argue that high microbial diversity in the eastern Mediterranean has evolved so that a system under starvation stress is able to utilise any quantity or quality of organic matter available. Clearly, more observations are required as well as the investigation of various plausible explanatory factors before reaching a conclusive pattern. We could cautiously speculate, however, that in the food-limited environment of the eastern Mediterranean Basin, the amount of organic carbon reaching the seafloor may be one of the factors driving microbial patterns, as suggested by the results of multivariate analysis for basin microbial richness.

It therefore appears that, although the two investigated benthic components, meiofauna and microbes, exhibit opposite bathymetric diversity patterns, food and topographic characteristics may be important factors in formulating these patterns in the deep Mediterranean Sea.

\subsubsection{Habitat-related diversity}

Although deep-sea diversity has been closely related to depth, it is now widely accepted that the high complexity of the seafloor also affects biodiversity levels and patterns (Levin et al., 2001, 2010; Vanreusel et al., 2010). Slopes and deep-sea basins are two major habitats with inherent differences due to the wide variability in environmental settings; this could, in turn, lead to differences in biological patterns and the communities they host. Nonetheless, results based on recent meiobenthic studies are rather contradicting. Danovaro et al. (2009a) and Gambi et al. (2010) found higher diversity in slopes based on major taxa and nematode species of European margins and on major taxa from the Mediterranean, respectively; Vanreusel et al. (2010) based on nematode genera reported no differences between these two habitats on a global scale; and Netto et al. (2005) in a deep-sea study off SE Brazil showed that the results differ depending on the taxonomic level of analysis (higher diversity at slope for major taxa, no differences for nematode families, higher diversity at deep-sea basin for nematode genera).

Our detailed study suggests that no difference in meiobenthic diversity between basin and slope ecosystems is to be expected in the central-eastern Mediterranean Basin. The number of major meiofaunal taxa was on average higher at the basin environment (except from the eastern Levantine), however, this difference was not statistically significant. Likewise, no difference between the two habitats was indicated for nematodes based on Jack1 richness estimator, although the observed number of nematode genera in slopes was significantly higher. Similar to meiofaunal abundance, increased heterogeneity within basins and slopes may be the explanatory factor for meiofaunal diversity as well, as has been previously suggested (Levin et al., 2001; Vanreusel et al., 2010; Levin and Sibuet, 2012). Local variability in various environmental conditions within each habitat, including substrate structure, hydrology, food input and disturbance, results in 
higher habitat complexity with probably more microhabitatspecific species. As a result, within-habitat variability may be higher than between habitats. We should point out though that the shape of the Jack1 curves reveals that whilst slope samples are sufficient for estimating nematode genera richness in the area (the curve reaching an asymptote), more basin samples are needed. This is rather a result to be expected as in deep-sea plains metazoan abundance is reduced and the animals are sparsely distributed, pointing to the need for a more intense sampling in order to collect more rare species. This becomes even more imperative due to the patchy distribution of meiobenthic metazoa (Giere, 2009).

So far, comparative microbial studies of the two studied habitats are not available. The first report on benthic microbial communities from different types of ecosystems was provided very recently by Zinger et al. (2011). Similar to the study of Sogin et al. (2006), this study demonstrated that the deep-sea sediments were more diverse than other types of ecosystems, such as vents, anoxic habitats and open ocean surface waters. Our study is the first comparing microbial communities from basin and slope ecosystems and clearly indicates that, opposite to meiobenthos, the deep-sea basins harbour more diverse microbial communities than the slopes. Similar to the bathymetric pattern we observed for microbial richness, this excess of diversity in the deep-sea basins is difficult to explain. Although limited environmental data are only considered here and available information on microbial communities is still very scarce, the higher microbial richness of the basin may be attributed to the higher organic carbon concentrations observed in several basin stations near the coast. It is hypothesised that these areas act as sinks of food sources, therefore offering higher availability and variability of food that ultimately is shaped into biodiversity. Indeed, Bienhold et al. (2012) in their study on Arctic microbial communities showed a positive energy-diversity relationship in oligotrophic regions. On the other hand, slope environments, in particular the steeper slopes, are known to experience strong perturbations due to current flow, landslides, or other sediment instability factors (Canals et al., 2009), which may affect benthic communities.

\subsubsection{Patterns of change in diversity and community structure}

Local diversity in deep-sea sediments is not only high but also quite variable (Rex and Etter, 2010). Following the discussion on diversity results, turnover diversity underlines the observed richness patterns. The high delta diversity of the two habitats for both levels of taxonomic analysis clearly indicates the high variation in meiofaunal composition in basin and slope ecosystems. When focusing exclusively on the nematode community, the variation should also be expected to be higher within the basin habitat. As has already been stated, the deep sea is characterised by a wide variety of habitats due to local topographic and other environ- mental features, which may also account for differences in meiofaunal communities. Indeed, differentiation diversity in marine sediments has been positively related to environmental heterogeneity (Ellingsen, 2002; Ellingsen and Gray, 2002; Anderson et al., 2006).

At smaller scale (within depth range), beta diversity of the basin and slope habitats ranges from low to moderate values (23-40\%), yet it shows a bathymetric trend of increasing values with depth, suggesting that the meiofauna community varies more as we move deeper. This is in agreement with the findings of Ellingsen (2002) that several measures of beta diversity correlate with depth. In a rather similar way, meiofaunal dissimilarity between slope and basin increases down to mid-slope depths $(\sim 1500 \mathrm{~m})$ after which it appears to be equally high, pointing to constantly high meiofaunal differences between basins and slopes closer to the abyssal zone.

Rex and Etter (2010) in their synthesis book on deep-sea biodiversity conclude that the rate of change in species composition is especially pronounced along depth gradients in the deep sea, and they further state that the rate of faunal replacement is roughly proportional to the rate of change in depth, therefore being higher in the bathyal zone and lower in the abyssal plain. In our study, the overall high values of nematode Jaccard dissimilarity between depth ranges, and the increase of Jaccard dissimilarity with depth in the case of major taxa composition indicate that in the Mediterranean Sea meiofaunal composition differs more towards the abyss. Ordination and PERMANOVA analysis shed further light on meiofaunal community structure, indicating that though meiofaunal structure differs significantly between the bathyal and the abyssal stations, nevertheless, the change is gradual, with assemblages of nearby depth categories appearing more similar than distant ones. Moreover, the fact that the deeper stations $(>3000 \mathrm{~m})$ group together suggest a stable synthesis of major meiofaunal taxa in abyssal sediments. A similar pattern was also reported by Danovaro et al. (2008) that found nematode assemblages to differ among three depth categories $(1000,3000,4000 \mathrm{~m})$ in the Mediterranean Sea. Apparently, the limited number of stations and consequently the few depth categories involved in that study could not have allowed the detection of the bathymetric gradient reported here. Similar to the univariate meiofaunal variables (abundance, diversity), community structure was also found to relate to depth and food availability, though the extent of the impact of the environmental variables differs between habitats and level of taxonomic analysis.

In their comprehensive study on global patterns of marine microbes, Zinger et al. (2011) found less variable communities in the deep-sea sediments compared to the coastal environment and suggested that this is due to the lower environmental dynamics of the nutrient-poor deep sea. In contrast, our results indicate a highly variable microbial community in the Mediterranean deep sea, exceeding $77 \%$ in dissimilarity even between samples of the same habitat, area or similar bathymetry, which could not be related to any of the studied 
environmental variables. Bienhold et al. (2012) found that the patterns of bacterial community structure in the Arctic deepsea sediments exhibit high correlations with pigment concentrations and lower but significant correlations with spatial distance and water depth. Although further investigation is needed to unravel patterns of microbial diversity, and focus on environmental variables, other than depth and food availability, that may act on microbial communities (e.g. microhabitat heterogeneity, seasonal or episodic events), the results of our study support the idea of a dynamic deep-sea environment characterised by habitat heterogeneity and regular or episodic disturbances.

\section{Conclusions}

Deep-sea slopes and basins are two habitats with inherent differences due to the wide variability in environmental settings. Nonetheless, heterogeneity within each habitat associated with local/regional features as well as variation in environmental conditions may lead to higher "within" than "between" habitat variability. Indeed, the results presented here indicate high within-habitat variability of meiobenthic diversity and suggest that neither strong nor consistent differences should be expected between basin and slope meiofauna in the deep Mediterranean Sea. In contrast to this, our study revealed that the basin environment hosts a much more diverse microbial community compared to slope. Depth appears once more as an overriding correlate with changes in deep-sea benthos, to a larger extent for meiofauna and in particular within the basin habitat. Meiofaunal abundance and richness diminish with depth and community structure gradually changes from the shallower bathyal to the abyssal sediments. This shift in meiobenthic community along the depth gradient is also evident in $\beta$ - and $\delta$-diversity components that are not only high within and between the investigated depth ranges, but also appear to increase with depth. Contrary to the metazoan patterns, microbial richness appears to increase with depth in the deep Mediterranean Sea and microbial composition varies greatly among all samples, even of the same bathymetry, habitat or area. Besides depth, food availability was also found to relate to the observed patterns although to different extents, depending on habitat type, benthic component and taxonomic level of analysis. This observation suggests that several other, perhaps depth-related, factors may drive the observed patterns.

\section{Supplementary material related to this article is available online at: http://www.biogeosciences.net/10/ 4861/2013/bg-10-4861-2013-supplement.zip.}

Acknowledgements. The authors would like to thank the captains and crews of the R/Vs Aegeao, Meteor, Maria S. Merian, and Sarmiento de Gaboa for their assistance during field operations and sampling. V. Kalogeropoulou and D. Mouriki are warmly acknowledged for assistance during various stages of the work conducted in the field and the laboratory. This research was jointly funded by the EU projects HERMES (Hot Spot Ecosystem Research on the Margins of European Seas FPVI, Contract No. GOCE-CT-2005511234-1), HERMIONE (Hotspot Ecosystem Research and Mans Impact on European Seas FP7-ENV-2008-1, Contract No. 226354), the EU FP6 ERA-network MarinERA, REDECO (Regional Drivers of Ecosystem Change and its Influence on Deep-Sea populations in the Mediterranean) and by the Greek General Secretariat of Research and Technology, Ministry of Education and Religious Affairs.

Edited by: A. Boetius

\section{References}

Anderson, M. J.: Permutation tests for univariate or multivariate analysis of variance and regression, Can. J. Fish. Aquat. Sci., 58, 626-639, 2001.

Anderson, M. J.: Distance-based tests for homogeneity of multivariate dispersions, Biometrics, 62, 245-253, 2006.

Anderson, M. J., Ellingsen, K. E., and McArdle, B. H.: Multivariate dispersion as a measure of beta diversity, Ecol. Lett., 9, 683-93, 2006.

Anderson, M. J., Gorley, R. N., and Clarke, K. R.: PERMANOVA + for PRIMER: Guide to Software and Statistical Methods, PRIMER-E: Plymouth, UK, 2008.

Baguley, J. G., Montagna, P., Lee, W., Hyde, L., and Rowe, G.: Spatial and bathymetric trends in Harpacticoida (Copepoda) community structure in the Northern Gulf of Mexico deep-sea, J. Exp.Mar. Biol. Ecol., 330, 327-341, 2006.

Bienhold, C., Boetius, A., and Ramette, A.: The energy-diversity relationship of complex bacterial communities in Arctic deepsea sediments, ISME J., 6, 724-732, 2012.

Bowman, J. P. and McCuaig, R. D.: Biodiversity, community structural shifts, and biogeography of prokaryotes within Antarctic continental shelf sediment, Appl. Environ. Microbiol., 69, 24632483, 2003.

Canals, M., Danovaro, R., Heussner, S., Lykousis, V., Puig, P., Trincardi, F., Calafat, A., Durrieu de Madron, X., and Palanques, A.: Cascades in Mediterranean submarine grand canyons, Oceanography, 22, 26-43, 2009.

Claesson, M. J., O’Sullivan, O., Wang, Q., Nikkila, J., Marchesi, J. R., Smidt, H., de Vos, W. M., Ross, R. P., and O'Toole, P. W.: Comparative analysis of pyrosequencing and a phylogenetic microarray for exploring microbial community structures in the human distal intestine, Plos One, 4, e6669, doi:10.1371/journal.pone.0006669, 2009.

Clarke, K. and Gorley, R.: PRIMER v6 User manual/Tutorial. PRIMER-E Ltd, Plymouth, 2006.

Colwell, R. K.: EstimateS: Statistical estimation of species richness and shared species from samples, Version 8, Persistent, www. purl.oclc.org/estimates, 2006.

Danovaro, R., Della Croce, N., Eleftheriou, A., Fabiano, M., Papadopoulou, N., Smith, C., and Tselepidis, A.: Meiofauna of 
the deep Eastern Mediterranean Sea: distribution, and abundance in relation to bacterial biomass, organic matter composition and other environmental factors, Prog. Oceanogr., 36, 329341,1995

Danovaro, R., Dinet, A., Duineveld, G., and Tselepides, A.: Benthic response to particulate fluxes in different trophic environments: a comparison between the Gulf of Lions-Catalan Sea (westernMediterranean) and the Cretan Sea (eastern-Mediterranean), Prog. Oceanogr., 44, 287-312, 1999.

Danovaro, R., Gambi, C., Lampadariou, N., and Tselepides, A.: Deep-sea nematode biodiversity in the Mediterranean basin: testing for longitudinal, bathymetric and energetic gradients, Ecography, 31, 231-244, 2008

Danovaro, R., Canals, M., Gambi, C., Heussner, S., Lampadariou, N., and Vanreusel, A.: Exploring benthic biodiversity patterns and hotspots on European margin slopes, Oceanography, 22, 1625, 2009a.

Danovaro, R., Bianchelli, S., Gambi, C., Mea, M., and Zeppilli, D.: $\alpha-, \beta-, \gamma-, \delta$ - and $\varepsilon$-diversity of deep-sea nematodes in canyons and open slopes of Northeast Atlantic and Mediterranean margins, Mar. Ecol. Prog. Ser., 396, 197-209, 2009 b.

Danovaro, R., Company, J. B., Corinaldesi, C., D' Onghia, G., Galil, B., Gambi, C., Gooday, A. J., Lampadariou, N., Luna, G. M., Morigi, C., Olu, K., Polymenakou, P., Ramirez-Llodra, E., Sabbatini, A., Sardà, F., Sibuet, M., and Tselepides, A.: Deep-sea biodiversity in the Mediterranean Sea: the known, the unknown, and the unknowable, PloS one, 5, e11832, doi:10.1371/journal.pone.0011832, 2010 .

Ellingsen, K. E.: Soft-sediment benthic biodiversity on the continental shelf in relation to environmental variability, Mar. Ecol. Prog. Ser., 232, 15-27, 2002.

Ellingsen, K. E. and Gray, J. S.: Spatial patterns of benthic diversity: is there a latitudinal gradient along the Norwegian continental shelf?, J. Anim. Ecol., 71, 373-389, 2002.

Gambi, C., Lampadariou, N., and Danovaro, R.: Latitudinal, longitudinal and bathymetric patterns of abundance, biomass of metazoan meiofauna: importance of the rare taxa and anomalies in the deep Mediterranean Sea, Adv. Oceanogr. Limnol., 1, 167-197, 2010.

Giere, O.: Meiobenthology: the microscopic motile fauna of aquatic sediments. Springer, Heidelberg, 2009.

Gray, J. S., Bjorgesaeter, A., and Ugland, K. I.: The impact of rare species on natural assemblages. J. Anim. Ecol., 74, 1131-1139, 2005.

Hedges, J. I. and Stern, J. H.: Carbon and nitrogen determination of carbonate-containing solids, Limnol. Oceanogr., 29, 657-663, 1984

Jones, R. T., Robenson, M. S., Lauber, C. L., Hamady, M., Knighy, R., and Fierer, N.: A comprehensive survey of soil acidobacterial diversity using pyrosequencing and clone library analyses, ISME J., 3, 442-453, 2009.

Kouridaki, I., Polymenakou, P. N., Tselepides, A., Mandalakis, M., and Smith, K.L. Jr: Phylogenetic diversity of sediment bacteria from the deep Northeastern Pacific Ocean: a comparison with the deep Eastern Mediterranean Sea, Int. Microbiol., 13, 143-150, 2010 .

Lambshead, P. J. D., Tietjen, J., Ferrero, T., and Jensen, P.: Latitudinal diversity gradients in the deep sea with special reference to North Atlantic nematodes, Mar. Ecol. Prog. Ser., 194, 159-167,
2000.

Lambshead, P. J. D., Brown, C. J., Ferrero, T. J., Mitchell, N. J., Smith, C. R., Hawkins, L. E., and Tietjen, J.,: Latitudinal diversity patterns of deep-sea marine nematodes and organic fluxes: a test from the central equatorial Pacific, Mar. Ecol. Prog. Ser., 236, 129-135, 2002.

Lampadariou, N., and Tselepides, A.: Deep-sea meiofauna from the Aegean Sea (eastern Mediterranean): spatial variability, Proceedings of the 6th Hellenic Symposium on Oceanography and Fisheries, 270-274, 2000.

Lampadariou, N. and Tselepides, A.: Spatial variability of meiofaunal communities at areas of contrasting depth and productivity in the Aegean Sea (NE Mediterranean), Prog. Oceanogr., 69, 1936, 2006

Lampadariou, N., Tselepides, A., and Hatziyanni, E.: Deep-sea meiofaunal and foraminiferal communities along a gradient of primary productivity in the eastern Mediterranean Sea, Sci. Mar., 73, 337-345, 2009.

Levin, L. A. and Sibuet, M.: Understanding Continental Margin Biodiversity: A New Imperative, Annu. Rev. Mar. Sci, 4, 79-112, 2012.

Levin, L. A., Etter, R. J., Rex, M. A., Gooday, J., Smith, C. R., Stuart, T., Hessler, R. R., and Pawson, D.: Environmental influences on regional deep-sea species diversity, Ann. Rev. Ecol. Syst., 32, 51-93, 2001.

Levin, L. A., Sibuet, M., Gooday, A., Smith, C., and Vanreusel, A.: The roles of habitat heterogeneity in generating and maintaining biodiversity on continental margins: an introduction, Mar. Ecol., $31,1-5,2010$.

Li, L., Kato, C., and Horikoshi, K.: Bacterial diversity in deep-sea sediments from different depths, Biodivers. Conserv., 8, 659677, 1999a.

Li, L., Kato, C., and Horikoshi, K.: Microbial diversity in sediments collected from the deepest cold-seep area, the Japan Trench, Mar. Biotechnol., 1, 391-400, 1999b.

Lorenzen, C. and Jeffrey, J.: Determination of chlorophyll in sea water, NESCO Tech. Pap. Mar. Sci. 35, 1-20, 1980.

Luna, G. M., Dell'Anno, A., Giuliano, L., and Danovaro, R.: Bacterial diversity in deep Mediterranean sediments: Relationship with the active bacterial fraction, and substrate availability, Environ. Microb., 6, 745-753, 2004.

Lykousis, V., Chronis, G., Tselepides, A., Price, N., Theocharis, A., Siokou-Frangou, I., Van Wambeke, F., Danovaro, R., Stavrakakis, S., Duineveld, G., Georgopoulos, L., Ignatiades, L., Souvermezoglou, A., and Voutsinou-Taliadouri, F.: Major outputs of the recent ultidisciplinary biogeochemical researches undertaken in the Aegean Sea, J. Marine Syst., 33/34, 313-334, 2002.

McArdle, B. H. and Anderson, M. J.: Fitting multivariate models to community data: a comment on distance-based redundancy analysis, Ecology, 82, 290-297, 2001.

Miljutin, D. M., Gad, G., Miljutina, M. M., Mokievsky, V. O., Fonseca-Genevois, V., and Esteves, A. M.: The state of knowledge on deep-sea nematode taxonomy: how many valid species are known down there?, Mar. Biodive., 40, 143-159, 2010.

Nacke, H., Thürmer, A., Wollnerr, A., Will, C., Hodac, L., Herold, N., Schöning, I., Schrumpf, M., and Daniel, R.: Pyrosequencingbased assessment of bacterial community structure along different management types in German forest and grassland soils, Plos 
One, 6, e17000, doi:10.1371/journal.pone.0017000, 2011.

Netto, S. A., Gallucci, F., and Fonseca, G. F. C.: Meiofauna communities of continental slope and deep-sea sites off SE Brazil, Deep-Sea Res. Pt. I, 52, 845-859, 2005.

Platt, H. M. and Warwick, R. M.: Freeliving marine nematodes, Part I. British Enoplids, Cambridge University Press, Cambridge, 1983.

Platt, H. M. and Warwick, R. M.: Freeliving marine nematodes. Part II. British Chromadorids, The Estuarine and Brackish-Water Sciences Association, Leiden, 1988.

Polymenakou, P. N., Bertilsson, S., Tselepides, A., and Stephanou, E. G.: Bacterial community composition in different sediments from the Eastern Mediterranean Sea: A comparison of four 16S rDNA clone libraries, Microb. Ecol., 50, 447-462, 2005a.

Polymenakou, P. N., Bertilsson, S., Tselepides, A., and Stephanou, E. G.: Links between geographic location, environmental factors and microbial community in sediments of Eastern Mediterranean Sea, Microb. Ecol., 49, 367-378, 2005 b.

Polymenakou, P. N., Lampadariou, N., Mandalakis, M., and Tselepides, A.: Phylogenetic diversity of sediment bacteria from the southern Cretan margin, Eastern Mediterranean Sea, Syst. Appl. Microbiol., 32, 17-26, 2009.

Poulos, S., Drakopoulos, P., and Collins, M.: Seasonal variability in sea surface oceanographic conditions in the Aegean Sea (Eastern Mediterranean): an overview, J. Marine Syst., 13, 225-244, 1997.

Psarra, S., Tselepides, A., and Ignatiades, L.: Primary productvity in the oligotrophic Cretan Sea (NE Mediterranean): seasonal and interannual variability, Prog. Oceanogr., 46, 187-204, 2000.

Quaiser, A., López-García, P., Zivanovic, Y., Henn, M. R., Rodriquez-Valera, F., and Moreira, D.: Comparative analysis of genome fragments of Acidobacteria from deep Mediterranean plankton, Environ. Microbiol., 10, 2704-2717, 2008.

Ramirez-Llodra, E., Brandt, A., Danovaro, R., De Mol, B., Escobar, E., German, C. R., Levin, L. A., Martinez Arbizu, P., Menot, L., Buhl-Mortensen, P., Narayanaswamy, B. E., Smith, C. R., Tittensor, D. P., Tyler, P. A., Vanreusel, A., and Vecchione, M.: Deep, diverse and definitely different: unique attributes of the world's largest ecosystem, Biogeosciences, 7, 2851-2899, doi:10.5194/bg-7-2851-2010, 2010.

Rex, M. and Etter, R.: Deep-sea biodiversity: Pattern and scale. Harvard University Press, Cambridge, Massachusetts, 2010.

Rex, M., Etter, R., Morris, J., Crouse, J., McClain, C., Johnson, N., Stuart, C., Deming, J., Thies, R., and Avery, R.: Global bathymetric patterns of standing stock and body size in the deep-sea benthos, Mar. Ecol. Prog. Ser., 317, 1-8, 2006.

Schauer, R., Bienhold, C., Ramette, A., and Harder, J.: Bacterial diversity and biogeography in deep-sea surface sediments of the South Atlantic Ocean, ISME J, 4, 159-170, 2010.
Schloss, P. D. and Handelsman, J.: Introducing DOTUR, a computer program for defining operational taxonomic units and estimating species richness, Appl. Environ. Microbiol., 71, 1501-1506, 2005.

Schuurmans Stekhoven Jr., J. H.: The freeliving marine nemas of the Mediterranean, I. The Bay of Villefranche, Mémoires Institut Royal des Sciences Naturelles de Belgique, 37, 1-220, 1950.

Soetaert, K. and Decraemer, W.: Eight new Tricoma species (Nematoda, Desmoscolecidae) from a deep-sea transect off Calvi (Corsica, Mediterranean), Hydrobiologia, 183, 223-247, 1989.

Soetaert, K. and Heip, C.: Nematode assemblages of deep-sea and shelf break sites in the North Atlantic and Mediterranean Sea, Mar. Ecol. Prog. Ser., 125, 171-183, 1995.

Soetaert, K. and Vincx, M.: Six new Richtersia species (Nematoda, Selachinematidae) from the Mediterranean Sea, Zoologica Scripta, 16, 125-142, 1987.

Sogin, M. L., Morrison, H. G., Huber, J. A., Welch, D. M., Huse, S. M., Neal, P. R., Arrieta, J. M., and Herndl, G. J.: Microbial diversity in the deep sea and the underexplored "rare biosphere", P. Natl. Acad. Sci. USA, 103, 12115-12120, 2006.

Soltwedel, T.: Metazoan meiobenthos along continental margins: a review, Prog. Oceanogr., 46, 59-84, 2000.

Tselepides, A. and Lampadariou, N.: Deep-sea meiofaunal community structure in the Eastern Mediterranean: are trenches benthic hotspots?, Deep-Sea Res. Pt. I, 51, 833-847, 2004.

Tselepides, A., Papadopoulou, N., Podaras, D., Plaiti, W., and Koutsoubas, D.: Macrobenthic community structure over the continental margin of Crete (South Aegean Sea, NE Mediterranean), Prog. Oceanog., 46, 401-428, 2000.

Tselepides, A., Lampadariou, N., and Polymenakou, P.: Benthic community structure and function of the deep Eastern Mediterranean Sea, Rapp. Comm. Int. Mer Medit., 38, 52, 2007.

Vanreusel, A., Fonseca, G., Danovaro, R., Da Silva, M. C., Esteves, A. M., Ferrero, T., Gad, G., Galtsova, V., Gambi, C., Da Fonsêca Genevois, V., Ingels, J., Ingole, B., Lampadariou, N., Merckx, B., Miljutin, D., Miljutina, M., Muthumbi, A., Netto, S., Portnova, D., Radziejewska, T., Raes, M., Tchesunov, A., Vanaverbeke, J., Van Gaever, S., Venekey, V., Bezerra, T. N., Flint, H., Copley, J., Pape, E., Zeppilli, D., Martinez, P. A., and Galeron, J.: The contribution of deep-sea macrohabitat heterogeneity to global nematode diversity, Mar. Ecol., 31, 6-20, 2010.

Warwick, R. M., Platt, H. M., and Somerfield, P. J.: Freeliving marine nematodes. Part III. Monhysterids. The Estuarine and Brackish-Water Sciences Association, Shrewsbury, 1998.

Whittaker, R. H.: Evolution and measurement of species diversity, Taxon, 21, 213-251, 1972.

Zinger, L., Amaral-Zettler, L. A., Fuhrman, J. A., Horner-Devine, M. C., Huse, S. M., Mark Welch, D. B., Martiny, J. B. H., Sogin, M., Boetius, A., and Ramette, A.: Global patterns of bacterial beta-diversity in seafloor and seawater ecosystems, PLoS ONE 6, e24570, doi:10.1371/journal.pone.0024570, 2011. 